\author{
Maciej MIŻEJEWSKI \\ Uniwersytet Jagielloński w Krakowie \\ presscd@gmail.com
}

\title{
KRYZYS MODELU ZARZĄDZANIA RAI I JEGO POLITYCZNE UWARUNKOWANIA
}

\section{ABSTRACT The crisis of the RAI's governance model and its political circumstances}

The political consequence of the RAI (Radiotelevisione Italiana) reform, made by Matteo Renzi's outgoing government, was the legitimacy of the government and, consequently, the loss of credibility of the public broadcaster. The opposition, criticizing the law, saw in it a serious threat to media pluralism and constitutional guarantees freedom of expression. When the ruling coalitions controlled the RAI, the credibility of the broadcaster, raised by the opposition, was only a component of political rhetoric. According to her, the new media law was designed to subdue the RAI's full control of the government and create the ground for future parliamentary elections. As a result, the RAI has been deprived of parliamentary scrutiny, so far held by a special parliamentary commission (Commisione Vigilanza RAI), whose influence has been significantly reduced. For many years the polemics of the Italian media system, the so-called duopoly, the dominant position of RAI and Mediaset, are of major importance in the political struggle in Italy.

Key words: political control over RAI, politicization of the media, media pluralism protection, constitutional freedom of expression, media in public debate

Słowa kluczowe: kontrola polityczna nad RAI, upolitycznienie mediów, ochrona pluralizmu medialnego, konstytucyjna wolność wypowiedzi, media w debacie publicznej 


\section{WPROWADZENIE}

Włoska ustawa medialna w obecnym kształcie oddaje RAI pod pełną kontrolę rządu. Oznacza to, że partia, która wygra wybory we Włoszech planowane na luty $2018 \mathrm{r}$. i utworzy rząd, określi jej zadania w procesie komunikowania politycznego. Warto zauważyć, że pomimo kształtu ustawy medialnej „misja” telewizji RAI jest w znaczącym stopniu formalna, a nie merytoryczna. Obecna opozycja ma duże szanse na wygranie wyborów w lutym 2018 r. Jest to jednak ugrupowanie o charakterze ewidentnie populistycznym, zasadnie oskarżane o brak demokracji wewnątrz samej organizacji. Lider opozycji, Beppe Grillo, były satyryk, zawdzięczający rozgłos występom w telewizji... RAI, kontestujący obecnie to medium jako miejsce komunikowania politycznego, a budujący swój wizerunek polityczny w mediach społecznościowych, arbitralnie zarządza stworzonym przez siebie ruchem politycznym. Ponadto w polityce zagranicznej Ruch Pięciu Gwiazd (Movimento 5 Stelle - M5S) prezentuje de facto charakter antyeuropejski (jest za wyjściem Włoch ze strefy euro) oraz wyraźnie prorosyjski. Praktyka działania Beppe Grilla świadczy o jego politycznej hipokryzji. Kreując się na orędownika demokracji, sam stanowi dla niej poważne zagrożenie.

Dymisja rządu Matteo Renziego, będąca konsekwencją referendum konstytucyjnego z grudnia 2016 r., potwierdziła, że model polityki państwa autorstwa byłego premiera, w którym jednym z kluczowych elementów była próba wykorzystania RAI w procesie konsolidacji władzy, nie został zaakceptowany zarówno przez opozycję, jak i przez włoskie społeczeństwo. Istotą porażki Matteo Renziego w referendum konstytucyjnym był jednak całokształt polityki byłego premiera (zwłaszcza problemy gospodarcze, a także kwestia kryzysu migracyjnego). Ważnym czynnikiem była też zapowiedź Renziego, iż w razie przegranej w referendum nie tylko poda się do dymisji, ale wręcz wycofa z życia politycznego (notabene pierwszej obietnicy dotrzymał, drugiej już nie). Renzi zapowiada, że jeśli w lutym 2018 r. Partia Demokratyczna wygra wybory, on sam ponownie stanie na czele rządu.

Dnia 12 grudnia 2016 r., w wyniku kryzysu politycznego, prezydent Włoch Sergio Mattarella powołał nowy gabinet: Paolo Gentiloniego. Zdefiniowanie roli RAI w procesie komunikowania politycznego pozostaje zatem w gestii obecnego rządu. Gabinet Paolo Gentiloniego, polityka Partii Demokratycznej (Partito Democratico), jest 64 rządem w powojennej historii Republiki Włoch. Jego skład oparty jest w dużej części na dotychczasowych strukturach rządu byłego premiera Matteo Renziego i ma zapewnione poparcie centrolewicowej większości w obu izbach włoskiego parlamentu. Gentiloni pełnił dotychczas funkcję ministra spraw zagranicznych w poprzednim rządzie. W $2014 \mathrm{r}$. zastąpił na tym stanowisku Federicę Mogherini, która została szefową unijnej dyplomacji. W dniach 13-14 grudnia 2016 r. utworzony przez niego gabinet otrzymał wotum zaufania odpowiednio w Izbie Deputowanych (Camera dei Deputati) i w Senacie ${ }^{1}$ (Il Senato).

A. de Gregorio, Gentiloni incassa la fiducia al Senato: 169 si, 99 contrari, „Corriere della Sera” 2016, 14 XII, [online] http://www.corriere.it/politica/16_dicembre_14/gentiloni-senato-la-fiducia-f8ea0df2-c1d6-11e6-bb17-ed756927e6e7.shtml, 17 XII 2016. 
Premier Gentiloni zapowiedział kontynuowanie reform rozpoczętych przez poprzedni gabinet. Celem nowego rządu jest przede wszystkim zażegnanie kryzysu finansowego i uchwalenie nowej ordynacji wyborczej, na podstawie której odbędą się przyszłe wybory parlamentarne, planowane na luty $2018 \mathrm{r}$.

\section{GŁÓWNE ZAŁOŻENIA WSPÓŁCZESNEJ POLITYKI MEDIALNEJ WŁOCH}

Szczególnego znaczenia w kontekście polityki medialnej Włoch nabiera rola obecnego premiera, zajmującego uprzednio ważne stanowiska w organach kontroli politycznej działalności nadawcy publicznego RAI. W latach 2005-2006 Gentiloni, jako deputowany do parlamentu, był m.in. przewodniczącym parlamentarnej komisji nadzoru nad RAI (Commisione Vigilanza RAI). Wówczas wielokrotnie krytykował publicznie ówczesny rząd Berlusconiego w odniesieniu do jego działalności medialnej². Później, jako minister komunikacji w rządzie Romano Prodiego w latach 2006-2008, postulował wdrożenie przepisów ograniczających kontrolę Berlusconiego nad włoskimi mediami ${ }^{3}$. Po wyborach w 2008 r. i utworzeniu czwartego rządu Silvio Berlusconiego Gentiloni ponownie uczestniczył w pracach komisji parlamentarnej nadzoru nad nadawcą publicznym RAI (Commissione parlamentare per l'indirizzo generale e la vigilanza dei servizi radiotelevisivi - CPIV).

Jeszcze przed zmianą na włoskiej scenie politycznej w grudniu 2016 r. opozycyjny Ruch Pięciu Gwiazd, liczący we włoskim parlamencie 126 deputowanych (91 posłów i 35 senatorów), którego liderem jest Beppe Grillo, zażądał na forum Parlamentu Europejskiego w Strasburgu, by Unia Europejska wszczęła procedurę ochrony państwa prawnego w UE wobec Italiił. Powodem było przyjęcie przez włoski parlament ustawy z dnia 28 grudnia 2015 r., dotyczącej reformy nadawcy publicznego RAI i sektora usług radiowo-telewizyjnych. Tym samym polityczna kontrola rządu nad nadawcą publicznym została silnie wzmocniona ${ }^{5}$. Rząd delegował bowiem do RAI swojego administratora (amministratore delegato), przyznając mu szerokie kompetencje m.in. w zakresie wpływu na obsadę kluczowych stanowisk redakcyjnych, jak również prawo do podpisywania kontraktów do wysokości $10 \mathrm{mln}$ euro ${ }^{6}$.

2 Riforma tv, via libera al decreto Gentiloni, „Coriere della Sera” 2006, 10 X, [online] http://www.corriere.it/Primo_Piano/Politica/2006/10_Ottobre/12/gentiloni.shtml, 17 XII 2016.

3 A. Mazurczyk, Kim jest Paolo Gentiloni, nowy premier Wtoch?, „Polityka” 2016, 13 XII, [online] https://www.polityka.pl/tygodnikpolityka/swiat/1686694,1,kim-jest-paolo-gentiloni-nowypremier-wloch.read, 17 XII 2016.

4 Conferenza Stampa: \#DenunciamoLaRai in UE, [online] http://www.beppegrillo.it/2016/02/conferenza_stampa_denunciamolarai_in_ue.html, 24 IX 2016.

5 M. Avvisati, Servizio pubblico radiotelevisivo, nuove tecnologie e principi costituzionali, „Quaderni Costituzionali” 2015, nr 4, s. 951-990.

6 Art. 2, p. 10 Legge 28 XII 2015, n. 220 Riforma della RAI e del servizio pubblico radiotelevisivo, Gazzetta Ufficiale, n. 11, 15 I 2016, [online] http://www.normattiva.it/uri-res/N2Ls?urn:nir:stato:legge:2015;220, $22 \times 2016$. 
Ponadto kontrowersje wzbudził wprowadzony ustawą nowy tryb wyboru członków zarządu $\mathrm{RAI}^{7}$. Zgodnie z jej zapisami dwóch członków zarządu będzie powoływanych przez Izbę Deputowanych, dwóch przez Senat, dwóch przed rząd i jeden przez pracowników spółki. W ten sposób zarząd RAI będzie odzwierciedlać większość parlamentarną, wspierającą rząd ${ }^{8}$.

Kadencja obecnego zarządu wygasa w 2018 r. Po tej dacie zarząd RAI wybrany zostanie według nowych zasad?. Tym samym nie będzie już powoływany przez CPIV, która dotychczas wyznaczała siedmiu z dziewięciu członków zarządu RAI, zgodnie z formułą politycznego parytetu ${ }^{10}$. Ponadto miała ona realny wpływ na powoływanie dyrektora generalnego oraz prezesa zarządu spółki. Tym samym rola komisji parlamentarnej w procedurze wyboru członków zarządu zostanie pominięta, co automatycznie pozbawi opozycję możliwości współdecydowania o składzie zarządu spółki ${ }^{11}$. Prezes RAI będzie wybierany przez nowy zarząd i zatwierdzany przez CPIV większością $2 / 3$ głosów. Jednakże jego kompetencje będą ograniczać się wyłącznie do wydawania decyzji w zakresie polityki zewnętrznej spółki oraz sprawowania nadzoru i kontroli nad działalnością wewnętrzną ${ }^{12}$.

Przeciw ustawie protestowały związki zawodowe dziennikarzy, m.in. Associazione Stampa Romana, organizacje społeczne: Libertà e Giustizia, Libera Cittadinanza, Sindacato Lavoratori Comunicazione CGIL, a także wiele uznanych autorytetów w dziedzinie włoskich mediów, takich jak Roberto Zaccaria (prezes RAI w latach 1998-2002), Antonio Di Pietro czy Gustavo Zagrebelsky. W sprawie reformy RAI w wymiarze europejskim wystosowali oni list otwarty, którego adresatem był prezydent Republiki Włoskiej - Sergio Mattarella ${ }^{13}$.

W liście otwartym z 30 grudnia 2015 r. jego sygnatariusze podkreślili, że po wieloletnich próbach reformy nadawcy publicznego RAI pojawiła się wreszcie szansa na faktyczne urzeczywistnienie tych planów ${ }^{14}$. Miała ona polegać na ponownym zdefiniowaniu usługi publicznej $\mathrm{w}$ sektorze radiowo-telewizyjnym ${ }^{15}$. Usługa ta powinna być

M.R. Allegri, Informazione e comunicazione nell'ordinamento giuridico italiano, Torino 2012.

Art. 2, p. 10, Legge 28 XII 2015, n. 220 Riforma della RAI e del servizio pubblico radiotelevisivo.

9 R. Borrello, Alcune notazioni sull'assetto del servizio pubblico radiotelevisivo in Italia, „Giurisprudenza Costituzionale" 2013, nr 4, s. 3635-3656.

10 Art. 20, p. 3, Legge 3 V 2004, n. 112 Norme di principio in materia di assetto del sistema radiotelevisivo e della RAI.

11 B. Caravita di Toritto, Libertà dei mezzi di informazione, innovazione tecnologica, effetti sulla democra$z i a$, „Nomos” 2015, nr 2, s. 1-7.

12 G.L. Cecchini, I servizi di interesse generale relativamente ai diritti dellinformazione nel settore telematico e televisivo, „Rivista della Cooperazione Giuridica Internazionale” 2011, nr 39, s. 83-99; P. Caretti, Diritto dell'informazione e della comunicazione, Bologna 2013.

13 Presidente Mattarella, rinvii alle camere la non riforma Rai!, IndigneRAI, [online] http://www.indignerai.it/presidente-mattarella-rinvii-alle-camere-la-non-riforma-rai, 22 X 2016.

14 A di Todaro, La natura giuridica della Rai (ancora) al vaglio delle sezioni unite, „Giurisprudenza Costituzionale” 2011, nr 6, s. 4742-4754; F. Massa Felsani, In tema di riforma della governance della Rai, „Il Diritto dell'Informazione e dell'Informatica” 2011, nr 1, s. 1-18.

15 G. Gardini, Dal „servizio pubblico” al „sistema” radiotelevisivo. La breve storia di un grande fallimento, „Diritto Pubblico” 2008, nr 2, s. 637-679. 
gwarantem wolności informacji, niezależnej i pluralistycznej, w trosce o pełną przejrzystość debaty publicznej ${ }^{16}$. Powinna urzeczywistniać obywatelskie prawo do wolności wyrażania opinii gwarantowanej konstytucyjnie ${ }^{17}$.

Sygnatariusze listu przypomnieli prezydentowi Republiki, że wartościami o priorytetowym znaczeniu dla Włoch, co notabene sam podkreślał w wystąpieniu inaugurującym swoją kadencję w dniu 3 lutego 2015 r., są pluralizm oraz wolność i niezależność informacji, będące bastionem demokracji ${ }^{18}$. Autorzy listu podkreślili, że jak nigdy wcześniej RAI wymaga obecnie radykalnych zmian, aby zachować swoją szczególną rolę w procesie komunikowania jako forum debaty publicznej, a stojąc na straży demokracji, służyć Republice ${ }^{19}$. Reforma ta wymaga więc gruntownej reorganizacji całego systemu publicznej radiofonii i telewizji ${ }^{20}$. Powinna położyć kres destrukcyjnym działaniom, które przyczyniły się do degradacji całego systemu radiowo-telewizyjnego.

W opinii sygnatariuszy głównymi zagrożeniami dla systemu są obecnie: polityczna kontrola zawartości informacji, złe zarządzanie, brak należnej mediom publicznym autonomii finansowej, brak strategii w zarządzaniu zasobami ludzkimi, utrata wiarygodności w oczach obywateli, nepotyzm oraz rosnąca liczba osób niekompetentnych, choć wysoko opłacanych, a rekomendowanych do pracy zarówno redakcyjnej, jak i administracyjnej w RAI przez partie polityczne (w tym także opozycyjne) czy też poszczególnych polityków. Notabene, trwa to od wielu dziesięcioleci, najpierw od czasów dominacji chadecji, następnie (w latach 80. XX w.) „trójpodziału” telewizji publicznej przez ówczesne trzy największe partie (chadecję, socjalistów i komunistów), poprzez epokę Berlusconiego i zwalczających go sił politycznych, aż do pierwszego 15-lecia XXI w. i obecnej sytuacji ${ }^{21}$.

Tymczasem, kiedy czytamy ustawę dotyczącą reformy RAI, jej zapisy sprawiają wrażenie powrotu do intencji ustawodawcy zawartych w prawie Gasparriego z 2004 r. Ustawa ta została wówczas zawetowana i w konsekwencji odesłana przez ówczesnego prezydenta Carlo Azeglio Ciampiego do ponownego rozpatrzenia jej przez Parlament. Prawo Gasparriego wzmacniało bowiem dominującą pozycję Silvio Berlusconiego w sektorze radiowo-telewizyjnym ${ }^{22}$.

Autorzy listu otwartego w konkluzji stwierdzili, że omawiana reforma RAI nie tylko utrwala szkodliwą praktykę działania politycznego, lecz także otwiera nowy rozdział

16 L. Bianchi, Libertà di espressione radiotelevisiva e servizio pubblico, Torino 2012.

17 G. De Minico, Silenzio elettorale e Costituzione, „Diritto e Società” 2010, nr 2, s. 221-238; C. Magnani, Pluralismo, informazione e radiotelevisione, Napoli 2014.

18 Discorso Mattarella, il testo integrale letto dal presidente della Repubblica, Il Fatto Quotidiano, [online] http://www.ilfattoquotidiano.it/2015/02/03/sergio-mattarella-testo-integrale-discorso-insediamento-montecitorio/1392714, 22 X 2016.

19 R. Mastroianni, Riforma del sistema radiotelevisivo italiano e diritto europeo, Torino 2004.

20 G.E. Vigevani, Appunti per uno studio sull'indipendenza del servizio pubblico radiotelevisivo, „Quaderni Costituzionali” 2012, nr 3, s. 587-614.

21 F. Monteleone, Storia della radio e della televisione in Italia, Venezia 2004.

22 Legge 3 V 2004, n. 112 Norme di principio in materia di assetto del sistema radiotelevisivo e della RAI-Radiotelevisione italiana Spa, Gazzetta Ufficiale, n. 104, 5 V 2004 - Supplemento Ordinario n. 82, [online] http://www.camera.it/parlam/leggi/04112l.htm, 22 X 2016. 
zmierzający do pełnej centralizacji obiegu informacji politycznejej. Ich zdaniem Włochy znalazły się obecnie w szczególnym momencie historycznym, w którym działalność mediów determinowana jest presją partii politycznych ${ }^{24}$. Autorzy listu do prezydenta Mattarelli podkreślili, że nowa ustawa, ich zdaniem, jest sprzeczna z art. 21 Konstytucji Włoch ${ }^{25}$. Jego treść potwierdza bowiem i chroni gwarancje wolności, niezależności i pluralizmu informacji publicznej ${ }^{26}$.

Ponadto zapisy nowej ustawy są sprzeczne z orzeczeniem Sądu Konstytucyjnego nr 225 z 10 lipca 1974 r. ${ }^{27}$, które określało prawne podstawy tworzenia pluralizmu we włoskich mediach, wprowadzając zasadę politycznej odpowiedzialności RAI przed parlamentem, a nie, jak dotychczas, przed rządem ${ }^{28}$. Niezależnie jednak od ówczesnej intencji Sądu Konstytucyjnego (Corte costituzionale) włoski system telewizyjny nie stał się faktycznie pluralistyczny, ale - co dowiódł także kryzys systemu partyjnego na początku lat 90. - został swoistym „łupem” partii parlamentarnych (zarówno koalicji rządowych, jak i sił opozycyjnych), niepozwalających na rzeczywistą autonomię systemu informacji politycznej we Włoszech, a przy tym był odtąd jednym z filarów tzw. partiokracji (partitocrazia) ${ }^{29}$.

Nowa ustawa w opinii sygnatariuszy jest również sprzeczna z dyrektywą Komitetu Ministrów Rady Europy z 15 lutego 2012 r., wzywającą kraje członkowskie do nowelizacji prawodawstwa $\mathrm{w}$ dziedzinie mediów publicznych w celu uwolnienia ich spod bezpośredniego wpływu rządu ${ }^{30}$.

\section{GŁÓWNE ZAŁOŻENIA REFORMY RAI I JEJ POLITYCZNE KONSEKWENCJE}

Dotychczas, mocą rozporządzenia z 31 lipca 2005 r., polityczną kontrolę nad RAI sprawowała specjalna komisja parlamentarna Commisione Vigilanza RAI, składająca się z 40 członków, będąca odzwierciedleniem układu sił politycznych we włoskim

23 G. Malinconico, La politica in televisione. Il difficile ruolo del Parlamento, „Federalismi.it” 2012, nr 2, s. 1-20.

24 A. D’Urbano, Par condicio, i candidati premier e (assenza) di pari opportunità, „Federalismi.it” 2013, nr 3, s. 1-12.

25 Costituzione della Repubblica Italiana, Gazzetta Ufficiale, n. 298, 27 XII 1947, [online] http://www. gazzettaufficiale.it/anteprima/codici/costituzione;jsessionid=D1U54Kgn50DGnYwTia2pqA_. ntc-as1-guri2a, 22 X 2016.

26 L'art. 21 Cost. e i principi costituzionali sulla libertà di informazione, [w:] R. Zaccaria, Diritto dell'informazione e della comunicazione, Padova 2002.

27 Sentenza 225/1974 della Corte costituzionale, Gazzetta Ufficiale, n. 187, 17 VII 1974, [online] http://www.giurcost.org/decisioni/1974/0225s-74.html, 22 X 2016.

28 G. Malinconico, La politica in televisione..., s. 1-20.

29 R. Zaccaria, A. Valastro, E. Albaniesi, Diritto dell'informazione e della comunicazione, Padova 2013.

30 Declaration of the Committee of Ministers on Public Service Media Governance adopted on 15 II 2012, [online] https://www.ebu.ch/files/live/sites/ebu/files/Publications/Reference\%20texts/ CoE\%20-\%20PSM/COE\%20REF\%20-\%20CM\%20Decl\%20PSM\%20governance.pdf, 1 X 2016. 
parlamencie ${ }^{31}$. Komisja ta wybierała do dziewięcioosobowego zarządu RAI siedem osób, a więc opozycja mogła mieć w zarządzie RAI swoich przedstawicielii ${ }^{32}$. Dwóch pozostałych członków zarządu, w tym prezesa, wybierał minister gospodarki. Prezes musiał mieć poparcie 2/3 zarządu, a więc pięciu z ośmiu pozostałych członków. Dyrektora generalnego wybierał zarząd ${ }^{33}$. Uczestniczył on w obradach zarządu RAI, ale bez prawa głosu ${ }^{34}$. Telewizja publiczna była więc de facto $\mathrm{w}$ posiadaniu partii politycznych, reprezentowanych w zarządzie $\mathrm{RAI}^{35}$.

W konsekwencji dotychczas obowiązującego rozwiązania legislacyjnego kolejne rządy we Włoszech, wybierając zarząd i prezesa RAI, musiały dążyć do kompromisu $\mathrm{z}$ opozycją w komisji parlamentarnej. Porozumienie polityczne niezbędne było również w samym zarządzie RAI. Dotyczyło to wyboru dyrektora generalnego i obsady najważniejszych stanowisk. Kompromis wymagał bowiem uzyskania 2/3 głosów zarówno w komisji parlamentarnej, jak i w zarządzie RAI ${ }^{36}$.

Kadencja obecnego, dziewięcioosobowego zarządu RAI, wybranego na mocy ustawy legge Gasparri, wygasa w sierpniu $2018 \mathrm{r} \cdot{ }^{37}$ Zgodnie z nową ustawą, uchwaloną przez parlament 28 grudnia 2015 r., zarząd RAI będzie liczyć siedem osób ${ }^{38}$. Po dwóch członków do zarządu wybiorą Izba Deputowanych i Senat (każdy deputowany i senator będzie mógł oddać głos wyłącznie na jednego kandydata), kolejnych dwóch członków do zarządu RAI desygnuje rząd, na wniosek ministra gospodarki i finansów (ministro dell'economia e delle finanze), zgodnie z kryteriami określającymi sposób wyboru członków organów zarządzających spółkami nadzorowanymi przez rząd. Kolejnego, siódmego członka zarządu wybiorą pracownicy RAI ${ }^{39}$.

Zgodnie z procedurą regulującą tryb wyboru członków zarządu RAI zgłaszanie kandydatur odbędzie się za pośrednictwem oficjalnych stron internetowych zarówno obu izb włoskiego parlamentu, jak i nadawcy publicznego RAI, na minimum $30 \mathrm{dni}$ przed planowanym wyborem. Na stronach tych pojawią się wówczas życiorysy kandydatów do zarządu RAI ${ }^{40}$.

Siódmy członek zarządu RAI wybrany zostanie przez walne zgromadzenie wszystkich pracowników spółki, zgodnie z procedurą ustaloną przez ustępujący zarząd.

31 Decreto Legislativo 31 VII 2005, n. 177 Testo unico della radiotelevisione”, Gazzetta Ufficiale, n. 208, 7 IX 2005, [online] http://www.camera.it/parlam/leggi/deleghe/05177dl.htm, 22 X 2016.

32 Tamże, art. 49, s. 9.

33 Tamże, art. 49, s. 12 b.

34 Tamże, art. 49, s. 11.

35 R. Borrello, Par condicio e radiotelevisione. Analisi dei principali ordinamenti europei, Vol. 1, Torino 2007.

36 F. Anania, Breve storia della televisione, Roma 2004.

37 Legge 3 V 2004, n. 112 Norme di principio in materia di assetto del sistema radiotelevisivo e della RAI-Radiotelevisione italiana Spa.

38 Art. 2, p. 6, Legge 28 XII 2015, n. 220 Riforma della RAI e del servizio pubblico radiotelevisivo.

39 O. Grandinetti, Il Testo unico dei servizi di media audiovisivi e radiofonici, „Giornale di Diritto Amministrativo" 2011, nr 2, s. 121-133.

40 Art. 2, p. 6, Legge 28 XII 2015, n. 220 Riforma della RAI e del servizio pubblico radiotelevisivo. 
Poszczególne kandydatury mogą być zgłaszane zarówno przez organizacje związkowe, będące sygnatariuszami umowy zbiorowej z RAI, jak i grupy liczące minimum 150 pracowników RAI. Zgłaszanie kandydatur musi nastąpić na co najmniej 30 dni przed planowanym wyborem ${ }^{41}$.

Członkiem zarządu RAI będzie mogła zostać osoba spełniająca warunki stawiane sędziom Sądu Konstytucyjnego (Corte Costituzionale), określone art. 135 Konstytucji Włoch ${ }^{42}$. Funkcję tę będą mogli sprawować: profesorowie zwyczajni, sędziowie (również w stanie spoczynku) oraz adwokaci, a także uznane autorytety w dziedzinie życia publicznego, kierujące się w działalności zawodowej niezależnością i bezstronnością. Kandydaci muszą wyróżniać się aktywnością w sferze ekonomicznej, naukowej, prawniczej, nauk humanistycznych lub nauk o komunikowaniu i posiadać niezbędne doświadczenie w zarządzaniu ${ }^{43}$.

Czas trwania kadencji członka zarządu RAI wynosi trzy lata, a dana osoba może zostać wybrana ponownie tylko jeden raz. Skład zarządu uwzględnia parytet płci i zachowuje proporcje w sferze różnych kompetencji zawodowych poszczególnych członków. Ustawa wyklucza możliwość współpracy członków zarządu RAI z innymi podmiotami sektora komunikowania, w tym zajmowania podobnych stanowisk, celem uniknięcia konfliktu interesów ${ }^{44}$. Ustawa nie dopuszcza łączenia stanowiska członka zarządu RAI z pełnieniem funkcji politycznych: ministra, wiceministra, podsekretarzy stanu w trakcie pełnienia mandatu oraz 12 miesięcy bezpośrednio przed wyborem ${ }^{45}$. Zarząd będzie zatwierdzać biznesplan, kosztorys wydatków w skali roku, a także inwestycji wieloletnich, powyżej $10 \mathrm{mln}$ euro ${ }^{46}$.

Prezes zarządu RAI będzie powoływany przez nowy zarząd spółki i zatwierdzany przez komisję parlamentarną ds. RAI CPIV większością $2 / 3$ głosów ${ }^{47}$.

W świetle nowej ustawy prezes RAI będzie pozbawiony jednak realnej władzy. Minister gospodarki i finansów wskaże bowiem dyrektora, któremu ustawa przyznaje szerokie uprawnienia, m.in. prawo głosu w zarządzie, mimo iż formalnie nie jest jego członkiem, a także prawo decydowania o obsadzie wszystkich ważniejszych stanowisk w RAI. Konsekwencją polityczną wprowadzonej w ustawie zmiany będzie wzmocnienie roli dyrektora generalnego jako przedstawiciela rządu ${ }^{48}$.

41 Tamże, art. 2, pkt 6-ter.

42 Costituzione della Repubblica Italiana, Gazzetta Ufficiale, n. 298, 27 XII 1947, [online] http://www. gazzettaufficiale.it/anteprima/codici/costituzione; jsessionid=D1U54Kgn50DGnYwTia2pqA_. ntc-as1-guri2a, 29 X 2016.

43 Note all'art. 2, pkt 6, Legge 28 XII 2015, n. 220 Riforma della RAI e del servizio pubblico radiotelevisivo.

44 La nuova televisione europea. Commento al Decreto Romani, red. V. Zeno-Zencovich, Rimini 2010.

45 S. Sica, Z. Zeno-Zencovich, Manuale di diritto dellinformazione e della comunicazione, Padova 2015.

46 Note all'art. 2, p. 9, Legge 28 XII 2015, n. 220 Riforma della RAI e del servizio pubblico radiotelevisivo.

47 Tamże, art. 2, p. 5.

48 V.M. Sbrescia, I servizi di media audiovisivi nel mercato europeo della radiotelevisione, Napoli 2012. 
Włoska ustawa medialna w obecnym kształcie pozwala zatem większości parlamentarnej wybrać czterech członków zarządu, ministrowi gospodarki i finansów dwóch kolejnych, a więc sześciu z siedmiu członków, co praktycznie wraz z nominowanym przez ministra gospodarki i finansów dyrektorem generalnym oddaje RAI pod pełną kontrolę rządu ${ }^{49}$. Oznacza to, że partia, która wygra wybory we Włoszech planowane na luty 2018 r. i utworzy rząd, w pełni podporządkuje sobie nadawcę publicznego RAI. Obecny zarząd RAI został wybrany w sierpniu 2015 r. na trzyletnią kadencję na zasadach wymagających kompromisu politycznego. Dzięki nowej ustawie, która weszła w życie 30 stycznia 2016 r., kompetencje dyrektora generalnego RAI, którym został zaufany premiera Renziego, Antonio Campo Dall'Orto, znacznie się zwiększyły.

W świetle nowo przyjętej ustawy zmienił się także model finansowania nadawcy publicznego RAI ${ }^{50}$. Dotyczy to trybu poboru abonamentu, który obecnie jest płacony wraz z rachunkiem za prąd w dwóch ratach. Pierwsza wynosi $70 \%$ kwoty, a druga 30 proc. Wpływy do budżetu z tytułu pierwszej raty w 2016 r. wyniosły $1 \mathrm{mld}$ euro. Egzekwowaniem poboru abonamentu zajmuje się włoski urząd skarbowy (Agenzia delle Entrate). Zmniejszyła się też wysokość abonamentu ze 113,50 euro do 100 euro rocznie. Kwota ta została podzielona i w ratach dodana do kolejnych rachunków za prąd. Od 2017 r. suma 100 euro zostanie rozłożona na pięć rat po 20 euro ${ }^{51}$.

Dotychczas ściągalność abonamentu we Włoszech była bardzo niska. Nie płaciło go 30\% gospodarstw domowych, co uszczuplało budżet RAI o $600 \mathrm{mln}$ euro rocznie. Dzięki nowej ustawie przychody RAI z abonamentu mają wzrosnąć nawet do 2 mld euro rocznie. Nowy tryb poboru abonamentu nie dotyczy mieszkańców 20 włoskich wysp, które mają własne, niewielkie autonomiczne sieci energetyczne, niepołączone $\mathrm{z}$ sieciami krajowymi ${ }^{52}$. Tym samym prowadzą odrębny system ewidencji swoich klientów. Są to wyspy określane mianem isole paradiso (rajskie wyspy): Ustica, Isole Tremiti, Levanzo, Favignana, Lampedusa, Linosa, Marettimo, Ponza, Giglio, Capri, Pantelleria, Lipari, Stromboli, Panarea, Vulcano, Salina, Alicudi, Filicudi, Capraia, Ventotene ${ }^{53}$. Pozostaną one zatem przy uprzednio obowiązującym systemie. Na liście tej nie znalazły się największe włoskie wyspy, takie jak Sycylia i Sardynia, które zostały objęte nową regulacją.

„Elektryczna izolacja” niektórych mniejszych wysp sprawiła, że nie zostały one włączone do złożonego systemu naliczania abonamentu razem $z$ energią ${ }^{54}$. Ten nowy mechanizm zakłada, że cztery instytucje, a wśród nich urząd skarbowy, Anagrafe Tributaria

49 O. Grandinetti, Disciplina televisiva italiana e diritto europeo. Gli sviluppi recenti, „Giornale di Diritto Amministrativo" 2008, nr 7, s. 808-815.

50 M.S.F. Hettiyakandage, Il sistema radiotelevisivo pubblico e privato e il suo finanziamento, Roma 2011.

51 https://canonerai.enelenergia.it, 6 XI 2016.

52 Canone RAI in bolletta? Non per tutti, escluse alcune „Isole paradiso”, [online] http://orizzontenergia. it/news.php?id_news=5414, 6 XI 2016.

53 Decreto 13 V 2016, n. 94, Regolamento recante attuazione dell'articolo 1, comma 154, della legge 28 XII 2015, n. 208, Canone Rai in bolletta, Gazzetta Ufficiale, Serie Generale, n. 129, 4 VI 2016.

54 Wtochy: Abonament RTV po raz pierwszy razem z pradem, [online] http://biznes.onet.pl/wiadomosci/ue/wlochy-abonament-rtv-po-raz-pierwszy-razem-z-pradem/z83g7p, 24 IX 2016. 
(włoski odpowiednik polskiego urzędu kontroli skarbowej) oraz dostawcy (Acquirente Unico dell'Elettricità) i dystrybutorzy energii, wymieniać będą między sobą informacje dotyczące odbiorców prądu, celem skutecznego egzekwowania abonamentu wraz z rachunkiem za energię elektryczną 55 .

\section{STANOWISKO KOMISJI EUROPEJSKIEJ WOBEC REFORMY RAI}

Opozycyjny Ruch Pięciu Gwiazd Beppe Grilla dopatruje się analogii w działaniach rządów we Włoszech i w Polsce, zmierzających do pełnego podporządkowania mediów publicznych władzy wykonawczej, co postrzega jako poważne zagrożenie dla demokracji.

Jakość pluralizmu medialnego, jako niezbędnego narzędzia dobrego funkcjonowania systemu demokratycznego, znacznie obniżyła się w obu krajach, co podkreśla w swoich komentarzach włoska opozycja ${ }^{56}$. Jej zdaniem w pełni podporządkowana rządowi telewizja publiczna funkcjonuje obecnie w obu krajach na podobnych zasadach, pełniąc wobec rządzących funkcję instrumentalną ${ }^{57}$.

Przypadek Włoch i Polski został jednakże potraktowany przez Unię Europejską na dwa różne sposoby. Wobec Polski została wszczęta procedura dotycząca „ochrony państwa prawnego", podczas gdy nie zastosowano podobnych środków wobec Włoch ${ }^{58}$. W opinii opozycji to nadawca publiczny RAI pełni obecnie funkcję głównego kanału informacyjnego rządu. Osłabia to kondycję włoskiej demokracji i jest sprzeczne z ideą pluralizmu medialnego. Efektem reformy RAI jest utrata kontroli politycznej nadawcy publicznego przez parlament i oddanie go do wyłącznej dyspozycji rządu ${ }^{59}$.

Minister gospodarki i finansów desygnuje bowiem administratora generalnego RAI, który mianuje dyrektorów anten telewizyjnych oraz wydawców serwisów informacyjnych. Mechanizm ten gwarantuje w konsekwencji wpływ rządu na kształt najbardziej opiniotwórczych programów nadawcy publicznego RAI. Włoska opozycja przywołuje przykład Polski, której rząd w tym względzie przyjął analogiczne rozwiązania, przekazując Ministerstwu Skarbu uprawnienia do powoływania zarządów i rad nadzorczych mediów publicznych, co w konsekwencji negatywnie wpływa na jakość pluralizmu medialnego. Eurodeputowany włoskiej partii opozycyjnej Movimento 5 Stelle, Dario Tamburrano, w tym kontekście przytacza wypowiedź pierwszego wiceprzewodniczącego Komisji Europejskiej Fransa Timmermansa, który stwierdził na

55 Isole d'Italia, Canone Rai ecco come va pagato, [online] http://www.notiziarioeolie.it/notizie/4046-isole-d-italia-canone-rai-ecco-come-va-pagato.html, 6 XI 2016.

Il sistema radiotelevisivo e la legalità europea, red. R. Mastroianni, Napoli 2006.

57 Blog Grillo: Rai fascista, riforma Renzi come quella di tv polacca, [online] http://www.askanews.it/politica/blog-grillo-rai-fascista-riforma-renzi-come-quella-di-tv-polacca_711714700.htm, 6 XI 2016.

58 Italia come la Polonia. Colpo di stato del governo nella TV pubblica, [online] http://www.davidborrelli. net/blog/post.php?idn=28, 6 XI 2016.

59 Rai, Fico: Italia come Polonia. Bruxelles vigili, [online] http://www.affaritaliani.it/affari-europei/ rai-fico-italia-come-polonia-bruxelles-vigili-404829.html, 6 XI 2016. 
forum Parlamentu Europejskiego, że wolność mediów i ich pluralizm sq nierozerwalnie zwiazane z prawami podstawowymi, na czele z konstytucyjna gwarancja wolności wyrażania opinii ${ }^{60}$.

Oficjalne stanowisko w sprawie reformy RAI przedstawili Komisji Europejskiej 7 stycznia 2016 r. w swojej interpelacji eurodeputowani Ruchu Pięciu Gwiazd: Dario Tamburrano, Isabella Adinolfi i Fabio Massimo Castaldo ${ }^{61}$. Interpelacja ta dotyczy nowego modelu zarządzania i finansowania nadawcy publicznego RAI i wzywa Komisję Europejską do zajęcia stanowiska w tej sprawie. Eurodeputowani wskazują na sprzeczność przepisów włoskiej ustawy medialnej z art. 11 Karty praw podstawowych Unii Europejskiej. Gwarantuje on każdemu prawo do wolności wypowiedzi, obejmujące także wolność posiadania poglądów oraz otrzymywania i przekazywania informacji i idei bez ingerencji władz publicznych i bez względu na granice państwowe ${ }^{62}$. Karta praw podstawowych podkreśla należny szacunek dla wolności i pluralizmu mediów ${ }^{63}$.

Zgłoszona interpelacja wskazuje ponadto na kwestię zmiany modelu finansowania RAI, polegającą na powiązaniu opłaty abonamentowej z rachunkiem za energię elektryczną, jako nową formą podatku ${ }^{64}$. W opinii eurodeputowanych jest to sprzeczne $\mathrm{z}$ art. 21 Karty praw podstawowych UE, zakazującym wszelkiej dyskryminacji.

W odpowiedzi na interpelację w komunikacie Komisji Europejskiej z 11 marca 2016 r. Günther Oettinger stwierdził, że zgodnie z protokołem nr 29 do Traktatu o Unii Europejskiej oraz Traktatu o funkcjonowaniu Unii Europejskiej władze Włoch posiadają pełną autonomię w określaniu formy, warunków i sposobów usług radiowo-telewizyjnych świadczonych przez nadawcę publicznego RAI. Analogiczną autonomię posiadają władze wszystkich państw wspólnoty w odniesieniu do definiowania modelu zarządzania oraz określania strategii dotyczącej funkcjonowania nadawców publicznych państw członkowskich UE. Do zakresu kompetencji Komisji Europejskiej nie należy więc badanie modeli finansowania nadawców publicznych państw członkowskich, jeżeli nie są one sprzeczne z obowiązującą na wspólnym rynku zasadą wolnej konkurencji65.

Zadaniem Komisji jest troska o zagwarantowanie poszanowania wolności i pluralizmu mediów, zgodnie z przyjętą Kartą praw podstawowych Unii Europejskiej. Dlatego

60 Pluralismo? All'UE va bene una RAI ridotta a TeleRenzi, [online] http://www.dariotamburrano.it/ riforma_rai_tv_di_stato_italia_polonia, 15 X 2016.

${ }_{61}$ Riforma della governance e del canone della RAI-Radiotelevisione Italiana S.p.A., [online] http://www. europarl.europa.eu/sides/getDoc.do?type=WQ\&reference=E-2016-000091\&language=IT, 15 X 2016.

62 M. Miżejewski, Ochrona pluralizmu w polityce medialnej Wtoch, Kraków 2013, s. 44-46, Societas Ksiegarnia Akademicka, 50.

63 Karta praw podstawowych Unii Europejskiej, 2010/C 83/02, Dziennik Urzędowy Unii Europejskiej C83/389, [online] https://bip.ms.gov.pl/Data/Files/_public/bip/prawa_czlowieka/onz/karta.pdf, $15 \times 2016$.

64 F. Donati, Lordinamento amministrativo delle comunicazioni, Torino 2007.

65 F. Bassan, Diritto delle comunicazioni elettroniche. Telecomunicazioni e televisione dopo la terza riforma comunitaria del 2009, Milano 2010; F. Bruno, G. Nava, Il nuovo ordinamento delle comunicazioni. Radiotelevisione, comunicazioni elettroniche, Milano 2006. 
też Komisja nie może wydać żadnych szczegółowych zaleceń w odniesieniu do modelu finansowania i zarządzania sektorem mediów publicznych ${ }^{66}$. Komisja może jedynie przyczynić się do promowania wolności i pluralizmu środków masowej komunikacji w Unii Europejskiej poprzez wsparcie finansowe dla niezależnych projektów wspierających pluralizm i wolność mediów ${ }^{67}$.

W kolejnej interpelacji do Komisji Europejskiej z 21 marca 2016 r., dotyczącej zastosowania odmiennej procedury w stosunku do Włoch i Polski, eurodeputowani włoskiej opozycji nawiązali do reformy modelu zarządzania mediami publicznymi przeprowadzonej w Polsce, która określiła nowy tryb wyboru władz spółek nadawców publicznych, pochodzących z bezpośredniej nominacji rządu. Podkreślili, że przyjęte w Polsce rozwiązania legislacyjne, w opinii polskiej premier, odzwierciedlają podobne działania podjęte przez rząd włoski. Tymczasem Komisja Europejska wyłącznie w przypadku Polski zdecydowała o wszczęciu unijnej procedury ochrony państwa prawa w odniesieniu do reformy systemu nadawców publicznych. Eurodeputowani włoskiej opozycji spytali więc Komisję Europejską o powody takiej decyzji ${ }^{68}$.

W odpowiedzi z 2 czerwca 2016 r. Komisja Europejska stwierdziła jedynie, że sytuacja we Włoszech, do której nawiązywali eurodeputowani, nie jest taka sama jak w Polsce, co w konsekwencji spowodowało wszczęcie tam procedury ochrony państwa prawa. Na posiedzeniu plenarnym Parlamentu Europejskiego z 19 stycznia 2016 r. na temat sytuacji w Polsce Komisja zażądała od polskich władz informacji o sytuacji Trybunału Konstytucyjnego oraz wprowadzonych zmianach w ustawie o radiofonii i telewizji69.

Pomimo takiego stanowiska Komisji Europejskiej politycy włoskiej opozycji, na czele z Beppe Grillem i Roberto Fikiem z Movimento 5 Stelle, konsekwentnie twierdzili, że reforma RAI była „zamachem stanu”. Ich zdaniem cenzurowanie informacji w RAI przyczyniło się do utraty wiarygodności nadawcy publicznego ${ }^{70}$. W swoich publicznych wystąpieniach wielokrotnie podkreślali, że wskutek reformy rządu Renziego RAI przestał pełnić funkcję kontroli władzy, a stał się dla rządzących wyłącznym kanatem politycznej indoktrynacji ${ }^{71}$.

66 A. Camilleri, Profili del sistema radiotelelevisivo nella fase di transizione sul digitale terrestre, Napoli 2010; F. Cardarelli, V. Zeno-Zencovich, Il diritto delle telecomunicazioni. Principi, normativa, giurisprudenza, Roma-Bari 1997.

67 Risposta di Günther Oettinger a nome della Commissione, [online] http://www.europarl.europa.eu/ sides/getAllAnswers.do?reference=E-2016-000091\&language=IT, 15 X 2016.

68 Riforma RAI, pluralismo informativo radio-televisivo, Italia e Polonia, [online] http://www.europarl.europa.eu/sides/getDoc.do?pubRef=-//EP//TEXT+WQ+E-2016-002343+0+DOC+XM$\mathrm{L}+\mathrm{V} 0 / / \mathrm{IT}, 6 \mathrm{XI} 2016$.

69 Risposta di Günther Oettinger a nome della Commissione, [online] http://www.europarl.europa.eu/ sides/getAllAnswers.do?reference=E-2016-002343\&language=IT, 15 X 2016.

70 P. Kowalczuk, Telewizja RAI pod kontrola, [online] http://www.rp.pl/Polityka/302099876-Telewizja-RAI-pod-kontrola.html\#ap-1, 24 IX 2016.

71 Il piano per la trasparenza in Rai proposta del M5S, [online] http://www.robertofico.it/il-piano-perla-trasparenza-in-rai-proposta-del-m5s, 12 XI 2016. 


\section{ORZECZNICTWO SĄDU KONSTYTUCYJNEGO (CORTE COSTITUZIONALE) W DZIEDZINIE POLITYKI MEDIALNEJ WE WŁOSZECH}

Współczesny włoski system radiowo-telewizyjny odznacza się relatywnie niskim poziomem pluralizmu ${ }^{72}$. Wynika to wprost $\mathrm{z}$ tradycji politycznej braku mediów niezależnych od władzy. Nawet w czasach I Republiki Włoskiej polityczna kontrola mediów stała się regułą budowania demokracji w tym $\mathrm{kraju}^{73}$. Powyższą regułę potwierdzał dekret prezydencki Luigiego Einaudiego z 1952 r. ${ }^{74}$ Polityczna kontrola rządu nad spółką pozostała niezmienna aż do $1975 \mathrm{r}$.

W pierwszym okresie, w latach 1954-1974, Sąd Konstytucyjny orzeczeniem z 1960 r. potwierdził zasadność istnienia monopolu RAI w eterze, klasyfikując system radiowo-telewizyjny jako usługę publiczną o szczególnym znaczeniu ${ }^{75}$. Wynikało to z treści zapisów ustawy zasadniczej, mocą której ustawodawca w interesie narodowym może przyznać państwu wyłączność na działalność w sektorze usług publicznych ${ }^{76}$. Taki zapis Konstytucji stworzył więc możliwość przyznania państwu wyłącznego prawa do sprawowania nadzoru nad wybranymi instytucjami sektora publicznego, w celu zagwarantowania właściwego wykonywania przez nie funkcji podyktowanych interesem wszystkich obywateli ${ }^{77}$.

Ponadto Sąd Konstytucyjny w wydanym orzeczeniu legitymizował zasadność istnienia monopolu państwa w eterze tzw. teorią niedoboru, czyli brakiem dostatecznej liczby wolnych częstotliwości umożliwiających działalność w eterze wielu nadawcom. W tej sytuacji ochrona pluralizmu wewnętrznego w RAI miała stanowić priorytet dla ustawodawcy w warunkach monopolu państwa w eterze ${ }^{78}$.

W połowie lat 70. ubiegłego wieku, biorąc pod uwagę rozwój technologiczny, Sąd Konstytucyjny zezwolił na działalność operatorom prywatnym w sektorze lokalnej telewizji kablowej oraz na odbiór i rozpowszechnianie na terytorium kraju programów nadawanych spoza granic Włoch ${ }^{79}$. I tym samym ostatecznie podważył zasadność

72 S. Ercolani, La concessione del servizio pubblico radiotelevisivo, „Il Diritto d'Autore” 2010, nr 1, s. 36-64.

73 A. Chimenti, Informazione e televisione. La libertà vigilata, Roma-Bari 2000; A. Chimenti, Lordinamento radiotelevisivo italiano, Torino 2007.

74 Decreto del presidente della Repubblica 26 I 1952, n. 180, Approvazione ed esecutorieta' della Convenzione per la concessione alla Radio Audizioni Italia Societa' per azioni del servizio di radioaudizioni e televisione circolare e del servizio di telediffusione su filo, Gazzetta Ufficiale, n. 82, 5 IV 1952, [online] http://www.gazzettaufficiale.it/eli/id/1952/04/05/052U0180/sg, 12 XI 2016.

75 Sentenza della Corte costituzionale n. 59, 1960, [online] http://www.giurcost.org/decisioni/1960/ 0059s-60.html, 12 XI 2016.

76 Art. 43, Costituzione della Repubblica Italiana, Gazzetta Ufficiale, n. 298, 27 XII 1947, [online] http://www.gazzettaufficiale.it/anteprima/codici/costituzione;jsessionid=D1U54Kgn50DGnYwTia2pqA_.ntc-as1-guri2a, 12 XI 2016.

77 A. Grasso, Prima lezione sulla televisione, Roma-Bari 2011.

78 G. Gardini, Le regole dell'informazione. Dal cartaceo al bit, Torino 2014.

79 Sentenza n. 225, 9 VII 1974, Gazzetta Ufficiale, n. 187, [online] http://www.cortecostituzionale.it/ actionSchedaPronuncia.do anno=1974\&numero=225, 12 XI 2016. 
istnienia monopolu państwa w eterze na poziomie lokalnym, w imię urzeczywistnienia konstytucyjnego prawa do wolności wyrażania opinii, co w konsekwencji spowodowało dynamiczny rozwój lokalnych stacji radiowych i telewizyjnych ${ }^{80}$.

Ponadto w orzeczeniu nr 225 z 1974 r. Sąd Konstytucyjny orzekt, że organy zarządzania i nadzoru koncesjonowanych spółek publicznych radia i telewizji powinny być wybierane przez parlament, a nie przez rząd, podkreślając w uzasadnieniu, że to właśnie parlament daje lepszą niż rząd gwarancję respektowania zasady pluralizmu politycznego ${ }^{81}$.

W następstwie wydanego orzeczenia ewolucyjne przechodzenie RAI pod kontrolę włoskiego parlamentu usankcjonowała ostatecznie ustawa nr 103 z 1975 r., która miała chronić pluralizm polityczny w mediach ${ }^{82}$. Wprowadziła ona zasadę nominowania członków zarządu RAI przez liczącą wówczas 40 członków komisję parlamentarną CPIV. Członkowie tej komisji byli powoływani zgodnie z zasadą parytetu przez marszałków obu izb włoskiego parlamentu (Camera dei Deputati, Il Senato) spośród przedstawicieli wszystkich ugrupowań parlamentarnych ${ }^{83}$. W świetle omawianej ustawy komisja parlamentarna mianowała 16 członków zarządu RAI ${ }^{84}$.

Ustawa z 1975 r. rozpoczęła nową erę kontroli politycznej RAI, określaną mianem lottizzazione. Było to efektem zmiany sytuacji politycznej we Włoszech, a mianowicie utraty dominacji przez chadecję, która dotychczas samodzielnie tworzyła rządy, i znaczącego wzmocnienia wpływów socjalistów, a zwłaszcza komunistów. Efektem kompromisu politycznego było podjęcie przez parlament zmian o charakterze legislacyjnym, które miały na celu podział wpływów partyjnych w mediach państwowych ${ }^{85}$.

Ich konsekwencją było m.in. wprowadzenie zasady obsadzania stanowisk dyrektorów poszczególnych anten oraz wydawców programów informacyjnych zgodnie z formułą politycznego parytetu ${ }^{86}$. Włoska chadecja (Democrazia Cristiana) zachowała kontrolę nad RAI UNO oraz RADIO 2, socjaliści (Partito Socialista Italiano) nad RAI DUE i RADIO 1, a komuniści (Partito Comunista Italiano) nad trzecim kanałem radiowym i utworzonym później kanałem telewizyjnym RAI TRE ${ }^{87}$. Tak określona praktyka działania politycznego wobec nadawcy państwowego RAI została utrwalona na wiele lat ${ }^{88}$.

80 Sentenza n. 202, 15 VII 1976, Gazzetta Ufficiale, n. 205, [online] http://www.cortecostituzionale.it/ actionSchedaPronuncia.do $?$ anno=1976\&numero=202, 12 XI 2016.

81 R. Zaccaria, A. Valastro, Diritto dell'informazione e della comunicazione, Padova 2002, s. 149-164.

82 Legge 14 IV 1975, n. 103 Nuove norme in materia di diffusione radiofonica e televisiva, Gazzetta Ufficiale, n. 102, [online] http://www.camera.it/_bicamerali/rai/norme/listitut.htm, 16 XI 2016.

Tamże, art. 1.

Tamże, art. 4, p. i.

P. Mezzanotte, La disciplina della par condicio nei regolamenti delle Autorità di vigilanza: i tratti salienti, „Federalismi.it” 2013, nr 3, s. 1-6.

F. Scaglione, Il regime giuridico delle frequenze radiotelevisive, „Diritto dell'Informazione e dell'Informatica" 2012, nr 4-5, s. 723-741.

La nuova televisione. Economia, mercato, regole, red. A. Nocita, G.B. Ramello, F. Silva, Bologna 2008.

M. Nunziata, Concorrenza e regolazione del mercato nel sistema delle comunicazioni, „GiustAmm.it” 2013, nr 3, s. 1-17. 
Sposób wyboru członków zarządu RAI przez komisję parlamentarną został zmieniony mocą ustawy z 4 lutego 1985 r. Do wyboru pierwszych 12 członków wymagana była wówczas większosś bezwzględna ${ }^{89}$. Pozostałych 4 członków wybierano zwykłą większością. Tym samym prawo wyboru członków zarządu RAI zostało wzmocnione na rzecz największych ugrupowań parlamentarnych, które w tej sprawie miały głos decydujący. W rezultacie koalicji rządowej mającej większość w parlamencie przypadała większość miejsc w komisji parlamentarnej, a co za tym idzie - we władzach RAI.

W latach 1976-1990 sukcesywnemu wzmacnianiu przez rząd kontroli politycznej nad RAI towarzyszył równolegle dynamiczny rozwój lokalnych, prywatnych nadawców telewizyjnych, którzy stopniowo zwiększali swoją obecność w eterze. Niektóre połączone sieci nadawców lokalnych łatwo zdołały pokryć swoim zasięgiem obszar niemal całego kraju. Proces „spinania sieci” doprowadził do postępującej koncentracji nadawców lokalnych w rękach nielicznych przedsiębiorców, na czele z Silvio Berlusconim ${ }^{90}$.

Ówczesny rząd socjalisty Bettino Craxiego faworyzował rozwój telewizyjnej spółki Berlusconiego Fininvest, przekształconej następnie w Mediaset. Główną siłą polityczną w pięciopartyjnej (Pentapartito) koalicji rządowej pozostawała wówczas chadecja, zaś zasadniczym motywem współpracy Craxiego i Berlusconiego były - oprócz wzajemnie dobrych relacji osobistych - tzw. kontakty biznesowe. Należy też pamiętać, iż pierwszy okres funkcjonowania Berlusconiego na włoskim rynku telewizyjnym miał przede wszystkim charakter komercyjny. Do czynnej polityki Berlusconi wszedł dopiero po upadku I Republiki, zwłaszcza wobec groźby (w roku 1994) zwycięstwa postkomunistycznej lewicy, co uniemożliwił utworzeniem i aktywnością polityczną partii o nazwie Forza Italia. Najbardziej kuriozalna sytuacja nastąpiła w trakcie rządów Silvio Berlusconiego, który uzyskiwał w ten sposób znaczący wpływ na politykę medialną zarówno nadawcy publicznego RAI, jak i nadawców komercyjnych, w tym Mediaset.

Ustawa nr 10 z 1985 r., sankcjonująca nadawanie programu w skali ogólnokrajowej przez połączone sieci nadawców lokalnych, w tym Mediaset Berlusconiego, została określona mianem „na ratunek Berlusconiemu” (salva Berlusconi). Sąd Konstytucyjny orzekł jednak jej niekonstytucyjność, gdyż podważała usankcjonowany dotychczas monopol RAI w eterze w skali ogólnokrajowej ${ }^{11}$. W wydanym orzeczeniu wezwał ustawodawcę do ochrony pluralizmu medialnego, poprzez przyjęcie rozwiązań legislacyjnych gwarantujących harmonijną koegzystencję operatorów publicznych i prywatnych w sektorze radiowo-telewizyjnym ${ }^{92}$.

89 Art. 6, p. 1, Legge 4 II 1985, n. 10, Gazzetta Ufficiale, n. 30, 5 II 1985, [online] http://www.gazzetta ufficiale.it/atto/vediMenuHTML; jsessionid=KwzTw+xNBc-GAZACexh5eg_.ntc-as4-guri2b ?atto.dataPubblicazioneGazzetta $=1985-02-05 \&$ atto.codiceRedazionale $=085$ U0010 \& tipoSerie $=$ serie generale\&tipoVigenza=originario, 16 XI 2016.

90 M. Pacillo, A. Preta, Televisione e mercati rilevanti a fini antitrust, „Concorrenza e Mercato” 2012, s. 727-764.

91 A. Pace, La Corte di cassazione ignora la storia, disapplica la legge e qualifica la Rai „ente pubblico”, „Giurisprudenza Costituzionale" 2010, nr 5, s. 4036-4042.

92 Sentenza della Corte costituzionale n. 826, 1988, [online] http://www.giurcost.org/decisioni/1988/ 0826s-88.html, 16 XI 2016. 
Reakcją ustawodawcy na orzeczenie Sądu Konstytucyjnego z 1988 r. było uchwalenie ustawy nr 223 z 1990 r., określanej mianem Legge Mammi ${ }^{93}$. Ustawa ta znosiła monopol RAI w eterze na szczeblu krajowym, tworząc prawne podstawy do stworzenia we Włoszech konkurencyjnego rynku nadawców ${ }^{94}$. Intencją ustawodawcy zawartą w preambule ustawy było zagwarantowanie w przekazach medialnych: pluralizmu, obiektywizmu, kompletności i niepodzielności informacji, otwartości na różne poglady, tendencje polityczne, spoteczne, kulturalne i religijne, z poszanowaniem praw i wolności odbiorców, gwarantowanych im przez konstytucje, a więc respektowanie przez nadawców fundamentalnych zasad dotyczacych funkcjonowania systemu radiowo-telewizyjnego oraz ich urzeczywistnienie, zarówno przez podmioty publiczne, jak i prywatne ${ }^{95}$. Tworzenie włoskiego prawa mediów miało się więc odbywać zgodnie z postanowieniami ratyfikowanej przez Włochy Europejskiej konwencji o telewizji ponadgranicznej z 1989 r. oraz Dyrektywy Unii Europejskiej nr 89/552/EWG, dotyczącej działalności telewizyjnej ${ }^{96}$.

Tymczasem ustawa Legge Mammi, zaadaptowana do ówczesnej sytuacji politycznej, sankcjonowała jedynie status quo i ze względu na to określona została mianem „fotograficznej" ${ }^{\prime 97}$. Zezwalała bowiem jednemu operatorowi na kontrolowanie maksymalnie trzech krajowych kanałów telewizyjnych, dając mu również prawo do czerpania wyłącznych zysków z reklam, utrwalając dotychczasową pozycję rynkową koncernu Berlusconiego, co potwierdził dekret z mocą ustawy z $1993 \mathrm{r}^{98}$

Sąd Konstytucyjny uznał jednak za niezgodne z konstytucją zapisy ustawy sprzyjające nadmiernej koncentracji kapitałowej w branży medialnej i utrwalające dominującą pozycję Silvio Berlusconiego. Wyrokiem z 5 grudnia 1994 r. określił je mianem lex imperfecta, wskazując na nieskuteczność uchwalonego przez parlament aktu prawnego ${ }^{99}$. W konsekwencji Sąd wezwał ustawodawcę do nowelizacji ustawy, w sposób eliminujący powstawanie pozycji uprzywilejowanych wśród nadawców

93 Legge 6 VIII 1990, n. 223, Disciplina del sistema radiotelevisivo pubblico e privato, Gazzetta Ufficiale, n. 185, [online] http://www.camera.it/_bicamerali/rai/norme/l223-90.htm, 16 XI 2016.

94 A. De Stefano, Concessioni radiotelevisive: possibilità di affitto del servizio da parte del concessionario, „Rassegna dell'avocatura di Stato” 2012, nr 3, s. 197-200.

95 O. Grandinetti, Numerazione del telecomando (lnc). Un groviglio sempre piu intricato, „Giornale di Diritto Amministrativo" 2014, nr 7, s. 722-732.

96 Convenzione europea sulla televisione transfrontaliera, $5 \mathrm{~V}$ 1989, [online] https://rm.coe.int/ CoERMPublicCommonSearchServices/DisplayDCTMContent ?documentId $=090000168$ 007b0f5, 16 XI 2016; Direttiva 89/552/CEE del Consiglio, del 3 X 1989, Relativa al coordinamento di determinate disposizioni legislative, regolamentari e amministrative degli Stati Membri concernenti l'esercizio delle attività televisive, [online] http://eur-lex.europa.eu/legal-content/IT/TXT/? uri=celex:31989L0552, 16 XI 2016.

97 R. Bianco, Diritto delle comunicazioni di massa, Roma-Bari 2007.

98 Decreto-legge 27 VIII 1993, n. 323, Provvedimenti urgenti in materia radiotelevisiva, Gazzet ta Ufficiale, Serie Generale, n. 260, 5 XI 1993, [online] http://www.gazzettaufficiale.it/eli/id/ 1993/11/05/093A6078/sg, 27 XI 2016.

99 Sentenza della Corte costituzionale n. 420, 1994, [online] http://www.giurcost.org/decisioni/1994/ 0420s-94.html, 27 XI 2016. 
w sektorze radiowo-telewizyjnym, w celu przeciwdziałania koncentracji w branży medialnej ${ }^{100}$.

Kryzys I Republiki i wejście na scenę polityczną Silvio Berlusconiego, który po raz pierwszy stanął na czele włoskiego rządu 10 maja 1994 r., opóźniły ponowne uchwalenie ustawy, w oczekiwaniu na którą dotychczas obowiązujące przepisy zostały jedynie prolongowane mocą dekretu legislacyjnego, przekształconego następnie w ustawę z 23 grudnia $1996 \mathrm{r}^{101}$

Zmiana na scenie politycznej i powołanie koalicyjnego, lewicowo-centrowego rządu Romano Prodiego 17 maja 1996 r. zaowocowały uchwaleniem nowej ustawy medialnej, określanej mianem Legge Maccanico z 1997 r., zgodnej z orzecznictwem Sądu Konstytucyjnego ${ }^{102}$. Ustawa określiła nowe, bardziej surowe limity antykoncentracyjne, zgodnie z którymi jeden operator nie mógł już kontrolować trzech sieci o zasięgu krajowym, lecz co najwyżej dwie. Sieć, która przekraczałaby ten limit, musiałaby zwolnić zajmowane dotychczas częstotliwości naziemne i nadawać przez satelitę ${ }^{103}$. Zapisy ustawy autorstwa włoskiej lewicy wymierzone były głównie w Mediaset, aby skutecznie przeciwdziałać nadmiernej koncentracji kapitałowej ${ }^{104}$. W zamian RAI miała zaprzestać emisji reklam w jednym ze swych trzech kanałów ogólnokrajowych. RAI TRE miał być odtąd finansowany wyłącznie $\mathrm{z}$ abonamentu ${ }^{105}$.

W istocie chodziło jednak o przeciwdziałanie nie tyle koncentracji kapitału czy też realnie istniejącemu „konfliktowi interesów” Berlusconiego, ile jego działalności - w tym momencie - jako lidera opozycji, ciągle groźnego dla rządzącej wówczas centrolewicy. Motyw polityczny był więc dużo bardziej wyraźny niż kwestie formalno-prawne.

W celu nadzorowania wypełniania zaleceń antymonopolowych przez nadawców (Legge Antitrust) mocą tejże ustawy został powołany Urząd ds. Gwarancji Komunikowania AGCOM (Autorità per le Garanzie nelle Comunicazioni), którego niezależność została jednak ograniczona poprzez tryb wyboru jej przewodniczącego.

100 G. Caggiano, La riforma del regime delle radiofrequenze nel quadro delle comunicazioni elettroniche, „Studi sull'Integrazione Europea” 2010, nr 1, s. 79-103.

101 Legge 23 XII 1996, n. 650, conversione in legge del decreto-legge 23 X /1996, n. 545, recante disposizioni urgenti per l'esercizio dell'attivita' radiotelevisiva e delle telecomunicazioni, interventi per il riordino della RAI S.p.a., Gazzetta Ufficiale, n. 300, 23 XII 1996, [online] http://www.parlamento.it/ parlam/leggi/96650l.htm, 27 XI 2016.

102 Legge 31 VII 1997, n. 249, Istituzione dell'Autorita' per le garanzie nelle comunicazioni e norme sui sistemi delle telecomunicazioni e radiotelevisivo, Gazzetta Ufficiale, n. 177, 31 VII 1997, [online] http://www.camera.it/parlam/leggi/97249l.htm, 27 XI 2016.

103 Tamże, art 3, s. 6.

104 F. Mezzanotte, Sull'alterazione degli equilibri concorrenziali del mercato televisivo connessa all'abuso di posizione dominante rivestita nel settore della rilevazione dei dati d'ascolto, „Il Diritto dell'Informazione e dell'Informatica" 2012, nr 4-5, s. 898-909.

105 M.R. Allegri, Il sistema radiotelevisivo in Italia (sintesi), opracowanie własne, zob. też: M.R. Allegri, Informazione e comunicazione... E. Matarazzo, La RAI che non vedrai. Idee e progetti sul servizio pubblico radiotelevisivo, Milano 2007; F. Devescovi, Ciao RAI, Roma 2013. Zob. też D. Pittèri, Pubblicitá in Italia, Bari 2006. 
Był on bowiem powoływany dekretem Prezydenta Republiki na wniosek premiera, w porozumieniu z ministrem komunikacji ${ }^{106}$. Dodatkowym ograniczaniem jego wyboru był wymóg akceptacji właściwej komisji parlamentarnej poprzez uzyskanie 2/3 głosów ${ }^{107}$.

Z chwilą powołania tego organu w 1997 r. AGCOM liczył łącznie dziewięć osób (ośmiu członków oraz przewodniczącego), wybieranych na siedmioletnią kadencję. Członkowie byli nominowani przez obie izby włoskiego parlamentu w równej proporcji (po czterech członków z każdej z izb). W 2012 r. liczba członków AGCOM została zmniejszona z dziewięciu do pięciu. Dwóch nominuje Izba Deputowanych, dwóch Senat, a przewodniczącego premier, w porozumieniu z ministrem rozwoju ekonomicznego. Wybór ten potwierdzany jest dekretem prezydenta Republiki ${ }^{108}$.

Słabość Legge Maccanico wynikała z faktu braku wskazania w ustawie terminu wejścia jej w życie, co wobec zmieniającej się sytuacji politycznej powodowało ciągłe odraczanie jej obowiązywania ${ }^{109}$. Ustawa zobowiązywała bowiem AGCOM do ponownego zdefiniowania i reorganizacji systemu radiowo-telewizyjnego, łącznie z przydziałem częstotliwości ${ }^{110}$. Konsekwencją było wydanie przez AGCOM rozporządzenia nr 326/2001 o wejściu w życie ustawy z dniem 31 grudnia 2003 r. ${ }^{111}$

Powrót do władzy Silvio Berlusconiego w 2001 r. spowodował celowe opóźnianie wejścia w życie ustawy godzącej w interesy Mediasetu. Ponownie więc odroczono termin jej obowiązywania, mocą dekretu legislacyjnego z 2003 r., określanego mianem „salva Rete 4” („na ratunek Rete 4" - jednej z trzech sieci wchodzącej w skład Mediasetu) ${ }^{112}$.

106 Art 1, p. 3., Legge 31 VII 1997, n. 249, Istituzione dell'Autorita' per le garanzie nelle comunicazioni e norme sui sistemi delle telecomunicazioni e radiotelevisivo.

107 R. Zaccaria, Diritto dell'informazione e della comunicazione, s. 172-185. Zob. też: M. Libertini, I rapporti tra Ministero a Autorità garante delle communicazioni, „Giornale Diritto Amministrativo” 2001, nr 12, s. 1287; O. Grandinetti, La radiotelevisione, „Trattato di Diritto Amministrativo” 2001, Vol. 2, s. 1828; L. Carlassre, Gli organi di governo del sistema, „Trattato di Diritto Amministrativo” 1999, Vol. 28, s. 119.

108 F. Giglioni, Il sistema delle communicazioni in Italia, opracowanie własne. Zob. też M. Miżejewski, Ochrona pluralizmu w polityce medialnej Wtoch, s. 172.

109 Decreto-legge 18 XI 1999, n. 433, Disposizioni urgenti in materia di esercizio dell'attivita' radiotelevisiva locale e di termini relativi al rilascio delle concessioni per la radiodiffusione televisiva privata su frequenze terrestri in ambito locale, Gazzetta Ufficiale, n. 14, 19 I 2000, [online] http://www.gazzettaufficiale.it/eli/id/2000/01/19/000A0477/sg, 27 XI 2016; Decreto-legge 23 I 2001, n. 5, Disposizioni urgenti per il differimento di termini in materia di trasmissioni radiotelevisive analogiche e digitali, nonche' per il risanamento di impianti radiotelevisivi, Gazzetta Ufficiale, n. 19, 24 I 2001, [online] http://www.parlamento.it/parlam/leggi/decreti/01005d.htm, 27 XI 2016.

110 M. Avvisati, AgCom e par condicio al tempo di Internet, „Osservatorio sulle Fonti” 2014, nr 2, s. 1-10.

111 V. Bellani, La convergenza fra radiotelevisione e comunicazioni elettroniche, „Il Diritto d'Autore” 2012, $\mathrm{nr}$ 1, s. 136-145; A. Corsi, Tv via Internet in Italia. Regolamentazione e normativa, Padova 2008.

112 Decreto-legge 24 XII 2003, n. 352 Disposizioni urgenti concernenti modalità di definitiva cessazione del regime transitorio della legge 31 luglio 1997, n. 249, Gazzetta Ufficiale, n. 300, 29 XII 2003, [online] http://www.parlamento.it/parlam/leggi/decreti/03352d.htm, 27 XI 2016; zob też: Tv, il governo approva il decreto salva Rete4, [online] http://www.repubblica.it/2003/l/sezioni/politica/gasparri4/ decre1/decre1.html, 27 XI 2016. 
Dekret ten został potwierdzony następnie uchwałą AGCOM z 2005 r., którego członków powołał już rząd Berlusconiego ${ }^{113}$.

Oficjalnym uzasadnieniem tej decyzji były jednak względy natury technicznej, a nie powody polityczne ${ }^{114}$. Zakładano bowiem, że do 2006 r. powinna zakończyć się faza eksperymentalna nadawania naziemnej telewizji cyfrowej i w związku z tym cały system radiowo-telewizyjny zrezygnuje z technologii analogowej, co będzie wiązało się z koniecznością ponownego przyznania częstotliwości dla naziemnej telewizji cyfrowej $^{115}$. Działania te podjęto mimo uprzedniego wyroku Sądu Konstytucyjnego, który jednoznacznie orzekł niezgodność z prawem ciągłego odraczania wejścia w życie ustawy Legge Maccanico z 1997 r. ${ }^{116}$

Drugi rząd Berlusconiego (2001-2005) stał się symbolem konfliktu interesów politycznych i ekonomicznych, co wynikało z faktu, że sprawowanie funkcji publicznej, pochodzącej z wyboru politycznego, zostało powierzone de facto grupie ekonomicznej, której zwierzchnikiem był premier włoskiego rządu. Niespotykana dotąd skala koncentracji kapitałowej w sektorze medialnym okazała się fenomenem w demokracjach zachodnioeuropejskich. Szefem rządu został bowiem przedsiębiorca zajmujący pozycję dominującą w sektorze wydawnictw periodycznych i rynku reklamy. Kontrolował on bezpośrednio trzy krajowe sieci komercyjne, wchodzące w skład koncernu Mediaset (Canale 5, Italia 1, Rete 4), a pośrednio, jako szef rządu, sprawował także nadzór polityczny nad działalnością trzech sieci nadawcy publicznego RAI.

Zwrócił na to uwagę włoskim parlamentarzystom były prezydent Włoch Carlo Azeglio Ciampi, który w swoim orędziu wystosowanym w 2002 r. apelował nie tylko o zagwarantowanie, lecz także o urzeczywistnienie zasady pluralizmu w dziedzinie środków masowego komunikowania, przypominając o nierozerwalnym związku między informacją a demokracją: zasada pluralizmu jest bowiem pozytywnym aspektem obywatelskiego prawa do informacji, gwarantowanego przez Konstytucję Włoch, które ustawodawca urzeczywistnił jedynie częściowo ${ }^{117}$. Potwierdza to dotychczasowe orzecznictwo Sądu Konstytucyjnego, które nie korelowało z terminowym i planowym działaniem ustawodawcy ${ }^{118}$.

113 Delibera n. 136/05/CONS, Interventi a tutela del pluralismo ai sensi della legge 3 maggio 2004, n. 112, Gazzetta Ufficiale della Repubblica Italiana 11 III 2005.

114 Vv. Aa., La televisione digitale. Temi e problemi. Commentario al d. lgs. 177/05 (T.U. della radiotelevisione), Milano 2006.

115 Legge 20 III 2001, n. 66 Conversione in legge, con modificazioni, del decreto-legge 23 I 2001, n. 5, recante disposizioni urgenti per il differimento di termini in materia di trasmissioni radiotelevisive analogiche e digitali, nonché per il risanamento di impianti radiotelevisivi, Gazzetta Ufficiale, n. 70, 24 III 2001, [online] http://www.parlamento.it/parlam/leggi/01066l.htm, 3 XII 2016, G. Fares, L'apertura del mercato radiotelevisivo, Torino 2008.

116 Sentenza della Corte costituzionale n. 466 del 2002, Gazzetta Ufficiale 1 a serie speciale, n. 47, 27 XI 2002, [online] http://www.giurcost.org/decisioni/2002/0466s-02.html, 3 XII 2016.

117 Messaggio alle Camere del Presidente della Repubblica Carlo Azeglio Ciampi del 23 luglio 2002 in materia di pluralismo e imparzialità dell'informazione, [online] http://presidenti.quirinale.it/Ciampi/dinamico/ContinuaCiampi.aspx ?tipo=discorso\&key=20101, 3 XII 2016.

118 R. Mastroianni, La direttiva sui servizi di media audiovisivi, Torino 2009. 
Silvio Berlusconi, zdeterminowany, aby ratować Rete 4, trzecią sieć telewizyjną swojego medialnego imperium Mediaset, jako szef rządu doprowadził w 2004 r. do uchwalenia nowej ustawy, zwanej Legge Gasparri ${ }^{119}$. Powód jej uchwalenia uzasadniano koniecznością przejścia na nadawanie cyfrowe, co w opinii rządu Berlusconiego czyniło bezprzedmiotowym wdrażanie zapisów ustawy Legge Maccanico, albowiem w konsekwencji miała zwiększyć się liczba kanałów telewizyjnych. Tym samym podważono zasadność orzeczenia Sądu Konstytucyjnego z 1994 r., sankcjonującego limity antykoncentracyjne dla kanałów telewizyjnych kontrolowanych przez jeden podmiot ${ }^{120}$.

Nowe prawo miało chronić interesy Berlusconiego, gdyż dotychczasowe regulacje, ustanowione jeszcze w 1997 r. przez Legge Maccanico, wprowadzały limit udziału w rynku reklamy na poziomie 30\% Tymczasem nowe prawo Gasparriego rozszerzało definicję rynku o wszystkie rodzaje nośników reklamy, tworząc tzw. zintegrowany system komunikacji, i obniżało dotychczasowy limit przychodów z reklamy dla jednego nadawcy do poziomu $20 \%$ w całym systemie, co osłabiło pozycję rynkową RAI. Regulacje te stworzyły dogodne warunki rozwoju medialnego imperium Berlusconiego w zintegrowanym sektorze komunikowania, służące głównie przedsięwzięciom ekonomicznym, powiązanym z nim kapitałowo.

Konwersja cyfrowa zakończyła się ostatecznie w 2012 r., w efekcie przyjętej przez parlament w 2010 r. ustawy oraz na mocy zapisów dekretu legislacyjnego z 2011 r., co pozwoliło Berlusconiemu przez kilka lat zachowywać pozycję dominującą w sektorze radiowo-telewizyjnym, funkcjonującym wciąż w oparciu o technikę analogową, nielimitowaną żadną skuteczną regulacją antykoncentracyjną ${ }^{121}$.

Sąd Konstytucyjny, orzekając w sprawach dotyczących polityki medialnej (orzeczenia nr 826 z 1988 r. oraz 420 z 1994 r.), uznał, że priorytetem dla ustawodawcy powinna być zawsze ochrona pluralizmu, i wskazał dwa sposoby jego urzeczywistnienia. Pierwszym z nich jest służba publiczna, określana mianem misji, dzięki której realizuje się tzw. pluralizm wewnętrzny, umożliwiający m.in. prezentowanie opinii publicznej zróżnicowanych poglądów i postaw społecznych poprzez otwarty dostęp do anteny różnych grup, środowisk czy partii politycznych. Drugim sposobem urzeczywistnienia tej zasady jest tzw. pluralizm zewnętrzny, który szanuje zasadę wolnej konkurencji, nawet jeśli nie w pełni się z nią identyfikuje ${ }^{122}$.

119 Legge 3 V 2004, n. 112 Norme di principio in materia di assetto del sistema radiotelevisivo e della RAI-Radiotelevisione italiana Spa.

120 Sentenza della Corte costituzionale n. 420, 1994, [online] http://www.giurcost.org/decisioni/1994/0420s-94.html, 3 XII 2016.

121 Legge 13 XII 2010, n. 220, Disposizioni per la formazione del bilancio annuale e pluriennale dello Stato, Gazzetta Ufficiale, n. 297, 21 XII 2010, Suppl. Ordinario n. 281, [online] http://www.gazzettaufficiale.it $/$ gunewsletter $/$ dettaglio.jsp ?service $=1 \&$ datagu $=2010-12-21 \&$ task=dettaglio \&numgu=297\&redaz=010G0238\&tmstp=1293096688623, 3 XII 2016; Decreto-legge 31 III 2011, n. 34, Disposizioni urgenti in favore della cultura, in materia di incroci tra settori della stampa e della televisione, Gazzetta Ufficiale, n. 74, 31 III 2011, [online] http://www.gazzettaufficiale.biz/atti /2011/20110074/011G0074.htm, 3 XII 2016; A. Mangani, I limiti di affollamento pubblicitario: dalla televisione a Internet?, „Mercato, Concorrenza, Regole” 2015, nr 2, s. 291-313.

122 Sentenza della Corte costituzionale n. 420, 1994; Sentenza della Corte costituzionale n. 826, 1988. 
Zdaniem Roberto Zaccarii prawo mające m.in. chronić pluralizm medialny, poprzez zapobieganie koncentracji kapitałowej i przeciwdziałanie osiąganiu pozycji dominującej, powinno być kompromisem pomiędzy realizacją konstytucyjnego prawa wolności konkurencji a urzeczywistnieniem konstytucyjnej gwarancji wolności wyrażania opinii, która realizuje się tylko wówczas, gdy mamy zagwarantowane prawo dostępu do różnych źródeł informacji oraz możliwość wyboru różnorodnych treści przekazów medialnych ${ }^{123}$.

W opinii autora współczesny rozwój nowych technologii nadawczych sprzyja urzeczywistnieniu zasady pluralizmu informacji, o co zabiegał na przestrzeni lat Sąd Konstytucyjny. Obecnie we Włoszech wszyscy nadawcy, zarówno krajowi, jak i lokalni, wykorzystują naziemne częstotliwości cyfrowe i w efekcie liczba kanałów dostępnych dla każdego nadawcy znacznie się zwiększyła. Ponadto szybkie rozprzestrzenianie się Internetu pozwala dziś korzystać z ogromnej liczby informacji pochodzących z wielu źródeł, oferowanych przez różnych dostawców. Spośród nadawanych obecnie w telewizji programów o zasięgu ogólnokrajowym zdecydowana większość to kanały bezpośrednio lub pośrednio powiązane z RAI lub Mediaset.

Dziś rynek nadawców naziemnej telewizji cyfrowej tworzy ośmiu operatorów, nadających w sieciach ogólnokrajowych, z których sześciu jest pionowo zintegrowanych z dostawcami usług medialnych. Wszyscy ci operatorzy, wykorzystujący przyznane im częstotliwości cyfrowe, zarządzają 19 multipleksami. Spośród tych ośmiu operatorów RAI i Mediaset wciąż kontrolują ponad 80\% rynku bezpłatnej, naziemnej telewizji cyfrowej. W sektorze telewizji płatnej liderem jest grupa $21^{\text {st }}$ Century Fox/Sky Italia, która nadaje także na platformie satelitarnej, posiadając $80 \%$ udziałów w rynku. Łącznie ci trzej nadawcy czerpią $90 \%$ zysków w całym sektorze radiowo-telewizyjnym ${ }^{124}$.

W toku dotychczasowych postępowań koncesyjnych, będących konsekwencją konwersji cyfrowej, faworyzowano tzw. nadawców historycznych, uniemożliwiając rozwój małym nadawcom prywatnym. W związku z tym Włochy znalazły się pod nadzorem Komisji Europejskiej w kwestii rozdysponowania „dywidendy cyfrowej”, czyli ubiegania się przez nadawców o pozostałe do podziału naziemne częstotliwości cyfrowe ${ }^{125}$. Utrwalony w świadomości Włochów duopol medialny RAI i Mediaset utrudnia pełne urzeczywistnienie idei pluralizmu, która paradoksalnie nie spotyka się z zainteresowaniem samych nadawców. Publiczne wezwanie do składania ofert dotyczących wolnych częstotliwości (dekret legislacyjny nr 12/2012), zmodyfikowane pod naciskiem Komisji Europejskiej, ze względu na faworyzowanie obecnych nadawców, spotkało się z niewielkim zainteresowaniem, a częstotliwości zostały rozdysponowane jedynie częśsiowo $^{126}$.

123 R. Zaccaria, Diritto dell'informazione e della comunicazione, s. 79-80.

124 Relazione annuale 2016 dell'AGCOM, [online] https://www.agcom.it/relazioni-annuali, 3 XII 2016.

125 C. Cambini, A. Sassano, T. Valletti, Un dividendo difficile da incassare, „Mercato, Concorrenza, Regole" 2010, nr 2, s. 295-310.

126 Decreto-legge del 18 X 2012, n. 179, Gazzetta Ufficiale, supplemento ordinario n. 194/L, n. 245, 19 X 2012, [online] http://www.agid.gov.it/sites/default/files/leggi_decreti_direttive/dl-18-ottobre-2012-n.179_0.pdf, 3 XII 2016. 
Kontrola obiegu informacji pozostaje wciąż w gestii RAI i Mediaset, podczas gdy pozostali operatorzy koncentrują swą działalność głównie na dostarczaniu treści rozrywkowych. Mimo iż od kilku lat Berlusconi nie pełni już funkcji premiera, wciąż jako lider opozycyjnej partii Forza Italia i jednocześnie właściciel największej sieci komercyjnej Mediaset posiada znaczący wpływ na kształtowanie treści przekazów informacyjnych.

Rząd nadal wpływa na działalność i strukturę programową RAI, ustalając wysokość rocznej opłaty abonamentowej, z której środki przeznaczone są na pokrycie kosztów związanych $\mathrm{z}$ wykonywaniem usługi publicznej w dziedzinie radiowo-telewizyjnej. Ustawa medialna, określając model finansowania nadawcy publicznego, zabrania wykorzystywania przez RAI środków abonamentowych do finansowania działalności niezgodnej ze świadczeniem usługi publicznej ${ }^{127}$. Ze względu na to, że RAI w dużej części finansowana jest $\mathrm{z}$ opłat abonamentowych, prawo określa limity dotyczące emisji reklam, bardziej restrykcyjne niż te określone dla nadawców prywatnych ${ }^{128}$.

Nadzieją na urzeczywistnienie idei pluralizmu politycznego we Włoszech miało być uchwalenie ustawy zawierającej gwarancje równego dostępu polityków do anteny. Tymczasem okazało się, że uchwalona w 2000 r. ustawa nr 28, określana mianem Par condicio, ma liczne mankamenty, na co zwróciły uwagę zarówno komisja parlamentarna (CPIV), jak i AGCOM ${ }^{129}$. Ustawa reguluje bowiem wyłącznie kwestie związane z komunikacją polityczną na antenach nadawców radiowych i telewizyjnych, z pominięciem Internetu, pozbawionego jako medium regulacji w tym zakresie. Dotyczy to również telewizji nadającej przez Internet, tzw. TV 2.0., której popularność stale się zwiększa. Dynamiczny rozwój nowych technologii, w tym wzrost znaczenia mediów społecznościowych w procesie komunikowania politycznego, determinuje potrzebę wypracowania nowych rozwiązań legislacyjnych, uwzględniających konstytucyjne prawo obywateli do otrzymywania informacji w warunkach pluralizmu medialnego ${ }^{130}$.

\section{PODSUMOWANIE}

Jeszcze przed dymisją rządu Matteo Renziego włoska opozycja, na czele z Ruchem Pięciu Gwiazd (Movimento 5 Stelle) Beppe Grilla oraz Ligą Północną (Lega Nord) Matteo Salviniego, bardzo krytycznie odniosła się do nowej ustawy medialnej, która zmierzała do całkowitego podporządkowania sektora publicznych usług radiowo-telewizyjnych władzy wykonawczej. Zdaniem opozycji uniemożliwia to wykonywanie misji przez nadawcę publicznego RAI w sposób niezależny i w pełni profesjonalny,

127 Art. 18, p. 4, Legge 3 V 2004, n. 112 Norme di principio in materia di assetto del sistema radiotelevisivo e della RAI- Radiotelevisione italiana Spa.

128 Art. 38, Decreto Legislativo 31 VII 2005, n. 177 Testo unico della radiotelevisione.

129 Relazione annuale 2015 dell'AGCOM, s. 22-23, [online] https://www.agcom.it/documents/10179/2294678/RELAZIONE+ANNUALE+2015_testo+completo/16c30a17-12c4-4637b79a-37d1d985945c, 10 XII 2016.

130 M. Di Filippo, Diritto comunitario e pluralismo dei mezzi di comunicazione di massa, Torino 2000. 
zgodnie z fundamentalną zasadą kontroli władzy sprawowanej przez media. Tymczasem nadawca publiczny RAI, pozostając w tak określonej strukturze zależności od władzy wykonawczej, utrwala jedynie istniejące podziały społeczne, znacznie ograniczając prawo dostępu do informacji ${ }^{131}$.

Opinie włoskich komentatorów politycznych, dotyczące uchwalonej przez ustępujący rząd Matteo Renziego ustawy medialnej, są podzielone. Wielu z nich podkreśla, że w telewizji RAI zakończył się czas partyjnych wpływów, określany mianem partitocrazia. Ich miejsce na antenie zajmie teraz rząd, co stanowi poważne zagrożenie dla demokracji. Jak pisze w swoim felietonie Antonella Piperno, jest to ryzykowna zmiana miejsc, która według opozycji podważa konstytucyjną zasadę wolności informacji oraz obywatelskie prawo do wolności wyrażania opinii ${ }^{132}$.

Według Antonello Giacomellego z Partii Demokratycznej (Partito Democratico), która zainicjowała uchwalenie reformy RAI, włoski nadawca stanie się dzięki niej nowoczesną, efektywnie i przejrzyście zarządzaną instytucją służby publicznej. Na jej czele stanie bowiem manager oraz zarząd wybrany przez obie izby parlamentu, a nie - jak dotychczas - przez komisję parlamentarną, na podstawie publicznie zgłoszonych kandydatur. Tym samym zostanie wzmocniony związek instytucjonalny nadawcy publicznego z obywatelami, jako faktycznymi reprezentantami społeczeństwa, a nie z partiami politycznymi ${ }^{133}$.

Konsekwencje polityczne będące efektem wprowadzonych zmian w ustawie medialnej opozycja postrzega w czarnych barwach. Potwierdzają to m.in. stenogramy posiedzeń komisji parlamentarnej (CPIV). Jeden z liderów partii opozycyjnej Movimento 5 Stelle Roberto Fico oświadczył, że jest to najgorsze prawo, jakie można było uchwalić w stosunku do nadawcy publicznego RAI. Ostrzega przed zagrożeniem dla pluralizmu i wolności informacji, a w konsekwencji dla stabilności włoskiej demokracji. Jego zdaniem Renzi chciał wzmocnienia kontroli politycznej nad RAI poprzez delegowanie administratora o nieograniczonych kompetencjach z nominacji włoskiego rządu. W warunkach każdej innej demokracji byłoby to niedopuszczalne $e^{134}$.

Kryzysem nadawcy publicznego RAI zaniepokojone są także włoskie związki zawodowe: Narodowa Federacja Prasy (Federazione Nazionale della Stampa Italiana - FNSI) oraz Związek zawodowy dziennikarzy RAI (Unione Sindacale Giornalisti RAI - USIGRai). Komentując reformę RAI, liderzy związkowi, tacy jak Vittorio

131 Conferenza Stampa: \#DenunciamoLaRai in UE, [online] http://www.beppegrillo.it/2016/02/conferenza_stampa_denunciamolarai_in_ue.html, 24 IX 2016.

132 A. Piperno, TeleRenzi, la riforma Rai è in onda, [online] http://www.panorama.it/news/politica/telerenzi-la-riforma-rai-e-onda, 9 X 2016.

133 Resoconto stenografico della seduta n. 495 del 31/07/2015 del Senato, [online] https://www.senato. it/japp/bgt/showdoc/frame.jsp?tipodoc $=$ Resaula\&leg=17\&id=00937280\&part=doc_dc-ressten rs-ddltit_sddeacmdddl1880rdredspr\&parse=no, 10 XII 2016.

134 Resoconto stenografico della Commissione parlamentare per l'indirizzo generale e la vigilanza dei servizi radiotelevisivi, seduta n. 78 di Mercoledì 10 II 2016, [online] http://documenti.camera.it/leg17/ resoconti/commissioni/stenografici/html/21/audiz2/audizione/2016/02/10/indice_stenografico.0078.html, 10 XII 2016. 
di Trapani (sekretarz USIGRai), Raffaele Lorusso (sekretarz generalny FNSI) oraz Giuseppe Giulietti (prezes FNSI), podkreślili, że Włochy już od dawna zajmują jedno z ostatnich miejsc na świecie pod względem urzeczywistnienia obywatelskiego prawa do informacji. Wprowadzona reforma RAI zwiększa jedynie ryzyko pogorszenia tego stanu rzeczy. Na mocy ustawy rząd włoski uzurpuje sobie bowiem pełną kontrolę personalną, finansową i programową nadawcy publicznego RAI, co determinuje sposób wykonywania tej szczególnej usługi publicznej, jaką jest realizacja misji ${ }^{135}$.

Przyjęte przez ustępujący rząd Matteo Renziego rozwiązania legislacyjne stworzyły sytuację zagrażającą pluralizmowi mediów, w której kolejne rządy mogą w pełni podporządkować sobie nadawcę publicznego RAI, wpływając na kształt debaty publicznej, zwłaszcza w okresie kampanii wyborczych. Odchodzący rząd Matteo Renziego tym samym jednoznacznie określił nowe zadania nadawcy publicznego RAI w procesie komunikowania politycznego we Włoszech.

\section{BIBLIOGRAFIA}

Allegri M.R., Informazione e comunicazione nell'ordinamento giuridico italiano, Torino 2012. Anania F., Breve storia della televisione, Roma 2004.

Avvisati M., AgCom e par condicio al tempo di Internet, „Osservatorio sulle Fonti” 2014, nr 2. Avvisati M., Servizio pubblico radiotelevisivo, nuove tecnologie e principi costituzionali, „Quaderni Costituzionali" 2015, nr 4.

Bassan F., Diritto delle comunicazioni elettroniche. Telecomunicazioni e televisione dopo la terza riforma comunitaria del 2009, Milano 2010.

Bellani V., La convergenza fra radiotelevisione e comunicazioni elettroniche, „Il Diritto d'Autore” 2012, nr 1.

Bianchi L., Libertà di espressione radiotelevisiva e servizio pubblico, Torino 2012.

Bianco R., Diritto delle comunicazioni di massa, Roma-Bari 2007.

Blog Grillo: Raifascista, riforma Renzi come quella di tv polacca, [online] http://www.askanews. it/politica/blog-grillo-rai-fascista-riforma-renzi-come-quella-di-tv-polacca_711714700. htm.

Borrello R., Alcune notazioni sull'assetto del servizio pubblico radiotelevisivo in Italia, „Giurisprudenza Costituzionale" 2013, nr 4.

Borrello R., Par condicio e radiotelevisione. Analisi dei principali ordinamenti europei, Vol. 1, Torino 2007.

Bruno F., Nava G., Il nuovo ordinamento delle comunicazioni. Radiotelevisione, comunicazioni elettroniche, Milano 2006.

Caggiano G., La riforma del regime delle radiofrequenze nel quadro delle comunicazioni elettroniche, „Studi sull'Integrazione Europea” 2010, nr 1.

135 Riforma RAI, FNSI E Usigrai: Doppio colpo all'autonomia della RAI servizio pubblico, [online] http:// www.usigrai.it/riforma-rai-fnsi-e-usigrai-doppio-colpo-allautonomia-della-rai-servizio-pubblico, 10 XII 2016. 
Camilleri A., Profili del sistema radiotelelevisivo nella fase di transizione sul digitale terrestre, Napoli 2010.

Canone RAI in bolletta? Non per tutti, escluse alcune „Isole paradiso”, [online] http://orizzontenergia.it/news.php?id_news $=5414$.

Caravita di Toritto B., Libertà dei mezzi di informazione, innovazione tecnologica, effetti sulla democrazia, „Nomos” 2015, nr 2.

Cardarelli F., Zeno-Zencovich V., Il diritto delle telecomunicazioni. Principi, normativa, giurisprudenza, Roma-Bari 1997.

Caretti P., Diritto dell'informazione e della comunicazione, Bologna 2013.

Carlassre L., Gli organi di governo del sistema, „Trattato di Diritto Amministrativo” 1999, Vol. 28.

Cecchini G.L., I servizi di interesse generale relativamente ai diritti dell'informazione nel settore telematico e televisivo, „Rivista della Cooperazione Giuridica Internazionale” 2011, nr 39.

Chimenti A., Informazione e televisione. La libertà vigilata, Roma-Bari 2000.

Chimenti A., Lordinamento radiotelevisivo italiano, Torino 2007.

Conferenza Stampa: \#DenunciamoLaRai in UE, [online] http://www.beppegrillo.it/2016/02/ conferenza_stampa_denunciamolarai_in_ue.html.

Corsi A., Tv via Internet in Italia. Regolamentazione e normativa, Padova 2008.

Devescovi F., Ciao RAI, Roma 2013.

Discorso Mattarella, il testo integrale letto dal presidente della Repubblica, Il Fatto Quotidiano, [online] http://www.ilfattoquotidiano.it/2015/02/03/sergio-mattarella-testo-integralediscorso-insediamento-montecitorio/1392714.

Donati F., Lordinamento amministrativo delle comunicazioni, Torino 2007.

Ercolani S., La concessione del servizio pubblico radiotelevisivo, „Il Diritto d'Autore” 2010, nr 1.

Fares G., L'apertura del mercato radiotelevisivo, Torino 2008.

Filippo M. Di, Diritto comunitario e pluralismo dei mezzi di comunicazione di massa, Torino 2000. Gardini G., Dal „servizio pubblico” al „sistema” radiotelevisivo. La breve storia di un grande fallimento, „Diritto Pubblico” 2008, nr 2.

Gardini G., Le regole dell'informazione. Dal cartaceo al bit, Torino 2014.

Grandinetti O., Disciplina televisiva italiana e diritto europeo. Gli sviluppi recenti, „Giornale di Diritto Amministrativo" 2008, nr 7.

Grandinetti O., Il Testo unico dei servizi di media audiovisivi e radiofonici, „Giornale di Diritto Amministrativo" 2011, nr 2.

Grandinetti O., La radiotelevisione, „Trattato di Diritto Amministrativo” 2001, Vol. 2.

Grandinetti O., Numerazione del telecomando (lnc). Un groviglio sempre piu intricato, „Giornale di Diritto Amministrativo" 2014, nr 7.

Grasso A., Prima lezione sulla televisione, Roma-Bari 2011.

Gregorio A. de, Gentiloni incassa la fiducia al Senato: 169 si, 99 contrari, „Corriere della Sera” 2004, 16 XII, [online] http://www.corriere.it/politica/16_dicembre_14/gentiloni-senato-la-fiducia-f8ea0df2-c1d6-11e6-bb17-ed756927e6e7.shtml.

Hettiyakandage M.S.F., Il sistema radiotelevisivo pubblico e privato e il suo finanziamento, Roma 2011.

Il piano per la trasparenza in Rai proposta del M5S, [online] http://www.robertofico.it/ il-piano-per-la-trasparenza-in-rai-proposta-del-m 5 s. 
Il sistema radiotelevisivo e la legalità europea, red. R. Mastroianni, Napoli 2006.

Isole d'Italia, Canone Rai ecco come va pagato, [online] http://www.notiziarioeolie.it/ notizie/4046-isole-d-italia-canone-rai-ecco-come-va-pagato.html.

Italia come la Polonia. Colpo di stato del governo nella TV pubblica, [online] http://www.davidborrelli.net/blog/post.php?idn=28.

Kowalczuk P., Telewizja RAI pod kontrola, [online] http://www.rp.pl/Polityka/302099876-Telewizja-RAI-pod-kontrola.html\#ap-1.

La nuova televisione. Economia, mercato, regole, red. A. Nocita, G.B. Ramello, F. Silva, Bologna 2008.

La nuova televisione europea. Commento al Decreto Romani, red. V. Zeno-Zencovich, Rimini 2010.

Libertini M., I rapporti tra Ministero a Autorità garante delle communicazioni, „Giornale Diritto Amministrativo" 2001, nr 12.

Magnani C., Pluralismo, informazione e radiotelevisione, Napoli 2014.

Malinconico G., La politica in televisione. Il difficile ruolo del Parlamento, „Federalismi.it” 2012, nr 2.

Massa Felsani F., In tema di riforma della governance della Rai, „Il Diritto dell'Informazione e dell'Informatica" 2011, nr 1.

Mastroianni R., La direttiva sui servizi di media audiovisivi, Torino 2009.

Mastroianni R., Riforma del sistema radiotelevisivo italiano e diritto europeo, Torino 2004.

Mazurczyk A., Kim jest Paolo Gentiloni, nowy premier Wtoch?, „Polityka” 2016, 13 XII, [online] https://www.polityka.pl/tygodnikpolityka/swiat/1686694,1,kim-jest-paolo-gentiloninowy-premier-wloch.read.

Matarazzo E., La RAI che non vedrai. Idee e progetti sul servizio pubblico radiotelevisivo, Milano 2007.

Mezzanotte F., Sull'alterazione degli equilibri concorrenziali del mercato televisivo connessa all'abuso di posizione dominante rivestita nel settore della rilevazione dei dati d'ascolto, „Il Diritto dell'Informazione e dell'Informatica" 2012, nr 4-5.

Mezzanotte P., La disciplina della par condicio nei regolamenti delle Autorità di vigilanza: i tratti salienti, „Federalismi.it” 2013, nr 3.

Minico G. De, Silenzio elettorale e Costituzione, „Diritto e Società” 2010, nr 2.

Miżejewski M., Ochrona pluralizmu w polityce medialnej Wtoch, Kraków 2013, Societas - Księgarnia Akademicka, 50.

Monteleone F., Storia della radio e della televisione in Italia, Venezia 2004.

Nunziata M., Concorrenza e regolazione del mercato nel sistema delle comunicazioni, „GiustAmm. it" 2013, nr 3.

Pace A., La Corte di cassazione ignora la storia, disapplica la legge e qualifica la Rai „ente pubblico”, „Giurisprudenza Costituzionale” 2010, nr 5.

Pacillo M., Preta A., Televisione e mercati rilevanti a fini antitrust, „Concorrenza e Mercato” 2012.

Pittèri D., Pubblicità in Italia, Bari 2006.

Pluralismo? All'UE va bene una RAI ridotta a TeleRenzi, [online] http://www.dariotamburrano.it/riforma_rai_tv_di_stato_italia_polonia.

Presidente Mattarella, rinvii alle camere la non riforma Rai!, IndigneRAI, [online] http://www. indignerai.it/presidente-mattarella-rinvii-alle-camere-la-non-riforma-rai. 
Rai, Fico: Italia come Polonia. Bruxelles vigili, [online] http://www.affaritaliani.it/affari-europei/rai-fico-italia-come-polonia-bruxelles-vigili-404829.html.

Riforma della governance e del canone della RAI-Radiotelevisione Italiana S.p.A., [online] http:// www.europarl.europa.eu/sides/getDoc.do type $=W Q \&$ reference $=E-2016-000091 \&$ language $=\mathrm{IT}$.

Riforma RAI, pluralismo informativo radio-televisivo, Italia e Polonia, [online] http://www. europarl.europa.eu/sides/getDoc.do?pubRef=-//EP//TEXT+WQ+E-2016-002343+ $0+\mathrm{DOC}+\mathrm{XML}+\mathrm{V} 0 / / \mathrm{IT}$.

Riforma tv, via libera al decreto Gentiloni, „Corriere della Sera”, 2006, 10 X, [online] http:// www.corriere.it/Primo_Piano/Politica/2006/10_Ottobre/12/gentiloni.shtml.

Risposta di Günther Oettinger a nome della Commissione, [online] http://www.europarl.europa. eu/sides $/$ getAllAnswers.do? reference=E-2016-000091\&language=IT.

Sbrescia V.M., I servizi di media audiovisivi nel mercato europeo della radiotelevisione, Napoli 2012.

Scaglione F., Il regime giuridico delle frequenze radiotelevisive, „Diritto dell' Informazione e dell’ Informatica" 2012, nr 4-5.

Sica S., Zeno-Zencovich Z., Manuale di diritto dell'informazione e della comunicazione, Padova 2015.

Stefano A. De, Concessioni radiotelevisive: possibilità di affitto del servizio da parte del concessionario, „Rassegna dell'avocatura di Stato” 2012, nr 3.

Todaro A. di, La natura giuridica della Rai (ancora) al vaglio delle sezioni unite, „Giurisprudenza Costituzionale" 2011, nr 6.

Urbano A. d', Par condicio, i candidati premier e (assenza) di pari opportunità, „Federalismi.it” 2013, nr 3.

Vigevani G.E., Appunti per uno studio sull'indipendenza del servizio pubblico radiotelevisivo, „Quaderni Costituzionali” 2012, nr 3.

Wtochy: Abonament RTV po raz pierwszy razem z prądem, [online] http://biznes.onet.pl/ wiadomosci/ue/wlochy-abonament-rtv-po-raz-pierwszy-razem-z-pradem/z83g7p.

Zaccaria R., Diritto dell'informazione e della comunicazione, Padova 2002.

Zaccaria R., Valastro A., Diritto dell'informazione e della comunicazione, Padova 2002.

Zaccaria R., Valastro A., Albaniesi E., Diritto dell'informazione e della comunicazione, Padova 2013. 
Dr Maciej MIŻEJEWSKI - adiunkt w Zakładzie Dziennikarstwa Instytutu Nauk Politycznych i Stosunków Międzynarodowych UJ. Członek Komitetu Naukowego Comunicazionepuntodoc Uniwersytetu La Sapienza w Rzymie. Prowadzi badania dotyczące polityki medialnej państw Unii Europejskiej, a zwłaszcza współczesnych Włoch, analizując m.in. wpływ orzecznictwa Sądu Konstytucyjnego (Corte Costituzionale) na rozwiązania legislacyjne służące ochronie pluralizmu mediów. Ważniejsze monografie: Ochrona pluralizmu w polityce medialnej Wtoch (Kraków 2013), Transformacja telewizji w Polsce po roku 1989 na tle zmian politycznych (Przemyśl 2005); artykuły naukowe: La crisi dell'ordine costituzionale in Polonia negli anni 2015 e 2016 con le sue conseguenze politiche („Nomos. Le Attualità nel Diritto” 2017, nr 1), Politicization of the media in the first decade of Polish membership in the European Union ("Nomos. Le Attualità nel Diritto" 2015, nr 1), Prawne gwarancje dostepu polityków do mediów publicznych w Polsce ("Studia Socialia Cracoviensia” 2015, nr 7), Krajowa Rada Radiofonii i Telewizji organem politycznej kontroli nadawców w Polsce („Politeja” 2014, nr 32), Wolność mediów a odpowiedzialność za stowo w debacie publicznej („Studia Socialia Cracoviensia” 2014, nr 1), Media i polityka we Wtoszech („Politeja” 2014, nr 25), Finansowanie mediów publicznych w polityce medialnej UE. Przyktad Polski, Wegier, Francji i Niemiec („Politeja” 2013, nr 23), Polityczne konsekwencje nowelizacji ustawy o radiofonii i telewizji („Universitas” 2003, nr 27-28), Il sistema radiotelevisivo polacco sullo sfondo delle trasformazioni politiche („Nomos. Le Attualità nel Diritto” 2004, nr 2). 